\title{
Vitamin D metabolism, sex hormones, and male reproductive function
}

\author{
Martin Blomberg Jensen \\ University Department of Growth and Reproduction, Rigshospitalet, Section 5064, Blegdamsvej 9, \\ 2100 Copenhagen, Denmark \\ Correspondence should be addressed to M Blomberg Jensen; Email: blombergjensen@gmail.com
}

\begin{abstract}
The spectrum of vitamin D (VD)-mediated effects has expanded in recent years, and VD is now recognized as a versatile signaling molecule rather than being solely a regulator of bone health and calcium homeostasis. One of the recently identified target areas of VD is male reproductive function. The VD receptor (VDR) and the VD metabolizing enzyme expression studies documented the presence of this system in the testes, mature spermatozoa, and ejaculatory tract, suggesting that both systemic and local VD metabolism may influence male reproductive function. However, it is still debated which cell is the main VD target in the testis and to what extent VD is important for sex hormone production and function of spermatozoa. This review summarizes descriptive studies on testicular VD metabolism and spatial distribution of VDR and the VD metabolizing enzymes in the mammalian testes and discusses mechanistic and association studies conducted in animals and humans. The reviewed evidence suggests some effects of VD on estrogen and testosterone biosynthesis and implicates involvement of both systemic and local VD metabolism in the regulation of male fertility potential.

Reproduction (2012) $\mathbf{1 4 4} 135-152$
\end{abstract}

\section{Introduction}

The spectrum of vitamin D (VD)-mediated effects has broadened in recent years beyond the regulation of bone health and calcium homeostasis (Holick \& Chen 2008). The main source of circulating VD is endogenous synthesis in the skin, where u.v.-B radiation from the sun initiates conversion of 7-dehydrocholesterol to inactive VD (cholecalciferol). Only small amounts of cholecalciferol are present in some dietary products, so in the absence of adequate sunlight, the supply of VD largely depends on fortification of dietary products or individual use of oral VD supplements (Holick \& Chen 2008). Cholecalciferol undergoes two hydroxylation steps to form the active VD compound $1,25(\mathrm{OH})_{2} \mathrm{D}_{3}$ (Fig. 1; Ponchon et al. 1969, Gray et al. 1972, Prosser \& Jones 2004). 25-Hydroxylation is mainly mediated by the hepatic enzyme CYP2R1 supported by CYP27A1. The newly formed $25-\mathrm{OHD}_{3}$ enters circulation and is subsequently hydroxylated by the renal $1 \alpha$-hydroxylase (CYP27B1) to $1,25(\mathrm{OH})_{2} \mathrm{D}_{3}$ that binds and activates the $\mathrm{VD}$ receptor (VDR) in the target cell, until it is inactivated by CYP24A1 (Prosser \& Jones 2004). Clinical VD status is determined by measuring serum level of $25-\mathrm{OHD}_{3}$, which is associated with bone mineral density (BMD), serum calcium level, and parathyroid hormone (PTH) secretion (Holick 2006, Lips 2006, Bouillon et al. 2008). Traditionally, four clinical subgroups are defined by serum levels of $25-\mathrm{OHD}_{3}$ : VD deficiency $<25 \mathrm{nmol} / \mathrm{l}$ (nM) $(<10 \mathrm{ng} / \mathrm{ml}), V D$ insufficiency $<50 \mathrm{nM}, V D$ sufficiency $\geq 50 \mathrm{nM}$, and high VD status $\geq 75 \mathrm{nM}$ (Dawson-Hughes et al. 2005, Ross 2011). In recent years, several studies suggested that $25-\mathrm{OHD}_{3}$ serum levels below $75 \mathrm{nM}(30 \mathrm{ng} / \mathrm{ml})$ should be considered insufficient, but the debate about optimal VD serum levels is ongoing (Heaney \& Holick 2011, Holick et al. 2011).

Results from $V d r$ knockout mice demonstrated that $V D R$ expression is necessary for most of the VDmediated effects (Bouillon et al. 2008). VDR is a classical steroid receptor ubiquitously expressed in most tissues and organs. After substrate binding (normally $\left.1,25(\mathrm{OH})_{2} \mathrm{D}_{3}\right)$, VDR heterodimerizes with RXR and mediates genomic effects in the nucleus through binding to $\mathrm{VD}$ response elements (VDRE) in target genes and subsequent regulation of transcription (Fig. 2; Haussler et al. 2011). The subcellular location of the receptor is important as VDR also mediates rapid nongenomic effects when situated in the membrane or cytoplasm (Fig. 2; Haussler et al. 2011). Cellular VD responsiveness is complex and depends not only on VDR expression. The liver and kidney were previously thought to be the only organs with the ability to activate $V D$, but extra-renal expression of CYP2R1, CYP27A1, CYP27B1, and CYP24A1 has been shown in many tissues initially thought only to be VD responsive (Nagakura et al. 1986, 


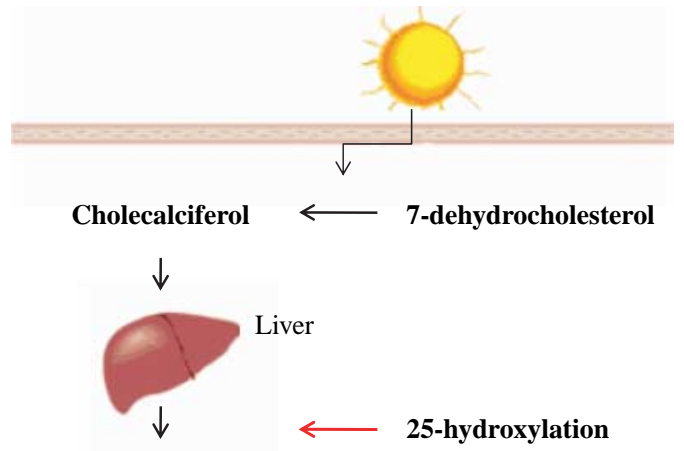

25-hydroxyvitamin D

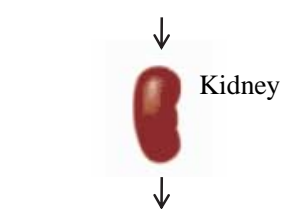

$\longleftarrow$ 1 $\alpha$-hydroxylation

1,25-dihydroxyvitamin $D$

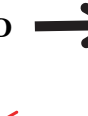

VDR

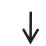

inactivation

\begin{tabular}{llllll}
\hline $\begin{array}{l}\text { Gene } \\
\text { name }\end{array}$ & $\begin{array}{l}\text { Vitamin D } \\
\text { metabolism }\end{array}$ & Protein function & $\begin{array}{l}\text { Chromosomal } \\
\text { location } \\
\text { human }\end{array}$ & $\begin{array}{l}\text { Chromos } \\
\text { omal } \\
\text { location } \\
\text { mice }\end{array}$ & $\begin{array}{l}\text { KO } \\
\text { model }\end{array}$ \\
\hline CYP2R1 & Activation & 25-hydroxylase & $11 p 15.2$ & 11 & - \\
CYP27A1 & Activation & 25-hydroxylase & 2q33-qter & 1 & - \\
CYP27B1 & Activation & 1 $\alpha$-hydroxylase & $12 q 13.1-q 13.3$ & 10 & + \\
VDR & Mediator & Receptor & $12 q 13.11$ & 15 & + \\
CYP24A1 & Inactivation & 24-hydroxylase & $20 q 13$ & 2 & +
\end{tabular}

Figure 1 Systemic vitamin D (VD) metabolism. VD metabolism normally starts in the skin, where u.v.-B radiation from the sun initiates conversion of 7-dihydrocholesterol to cholecalciferol. Cholecalciferol is not biologically active but has to undergo two enzymatic steps before active $1,25(\mathrm{OH})_{2} \mathrm{D}_{3}$ is formed. Normally, 25-hydroxylation takes place in the liver by CYP2R1, while $1 \alpha$-hydroxylation is conducted in the kidney following tubular reabsorption by CYP27B1. The activated form of VD $1,25(\mathrm{OH})_{2} \mathrm{D}_{3}$ mediates its effect through the $\mathrm{VD}$ receptor (VDR) until inactivated by 24 -hydroxylation. The table below indicates the factors involved in VD metabolism. $\mathrm{KO}$ refers to mice knockout model.
Choudhary et al. 2005). This implies that in addition to the mandatory presence of VDR, the cellular response to VD is influenced by the cells' uptake of substrate and metabolism of the circulating forms of VD (Fleet 2008). Moreover, cellular VD metabolism is not as tightly regulated as the systemic VD metabolism. Local VD metabolism is very sensitive to the intracellular concentration of $1,25(\mathrm{OH})_{2} \mathrm{D}_{3}$ as the promoter of the CYP24A1 gene contains activating VDREs and the transcription is upregulated by $1,25(\mathrm{OH})_{2} \mathrm{D}_{3}$ to titrate an adequate cellular VD response and to balance activation of VDR in response to increased intracellular $1,25(\mathrm{OH})_{2} \mathrm{D}_{3}$ (Haussler et al. 2011).

While the essential role of VD in bone turnover and function and for calcium transportation in intestine and kidney is well established knowledge, the involvement of VD in male reproductive function has only relatively recently been identified. This review summarizes and evaluates the expression of $V D R$ and VD metabolizing enzymes in the testes of mammals supported by association and functional studies in order to clarify the role of serum and in vitro effects of VD on male reproductive function.

\section{VDR expression and signaling in testes}

Kream et al. (1977) showed that $1,25(\mathrm{OH})_{2} \mathrm{D}_{3}$ has a specific high-affinity binding site to cytoplasmic homogenates of the rat testis. The testis-specific binding of $1,25(\mathrm{OH})_{2} \mathrm{D}_{3}$ differed from the known binding site in plasma (supposedly VD binding protein) and was not influenced by competitive binding of $25-\mathrm{OHD}_{3}$ in the nanomolar range. This is in line with the later reported difference in dissociation constant $\left(K_{\mathrm{d}}\right)$ for the two VDR substrates. The following studies (predominantly using an autoradiographic approach) corroborated the presence of VDR in testes from both mice and rats, mainly in tissues obtained from young animals (Merke 


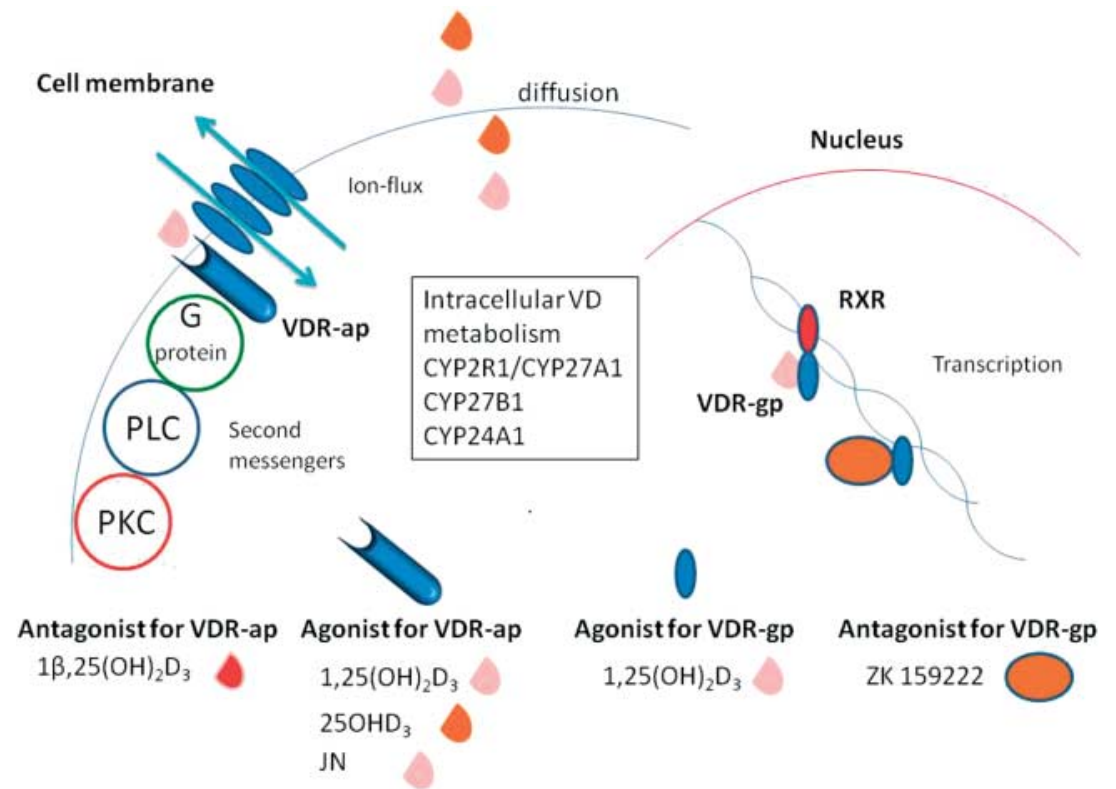

Figure 2 Schematic overview of the proposed cellular metabolism and actions of vitamin $\mathrm{D}$ (VD). The VD receptor (VDR) mediates rapid actions when situated at the membrane or in the cytoplasm through ion channel activation or modulation of second messengers. The VD progenitors diffuse freely across the plasma membrane and the intracellular concentration of VD progenitors is titrated by the presence of the VD metabolizing enzymes. VDR regulates transcription of $\sim 1000$ genes in the nucleus. VDR heterodimerizes with RXR that subsequently binds to VDRE in target genes and regulates transcription. VDR also mediates rapid nongenomic effects through the alternative ligandbinding pocket (VDR-ap), while genomic effects are mediated through the genomic ligand-binding pocket (VDR-gp).

et al. 1983, 1985, Walters et al. 1983, Levy et al. 1985a, 1985b, Schleicher et al. 1989). It should be mentioned that receptors for $1,25(\mathrm{OH})_{2} \mathrm{D}_{3}$ were present in similar amounts in isolated seminiferous tubules and interstitial tissue of adult rats (Levy et al. 1985a). Hereafter, Sertoli cells were introduced as the main VD target cell in rodent testes, as an autoradiographic approach showed nuclear VDR binding exclusively in mice Sertoli cells, while the presence of VDR was sparse and predominantly cytoplasmic in germ cells (Schleicher et al. 1989). Subcellular expression of $V D R$ determines the downstream signaling pathway (genomic or nongenomic) (Fig. 2). VDR is expressed in both nucleus and cytoplasm of primary cultures of immature Sertoli cells and in the immature mice Sertoli cell line TM4, and $1,25(\mathrm{OH})_{2} \mathrm{D}_{3}$ mediates fast nongenomic effects in both cell lines (Akerstrom \& Walters 1992, Majumdar et al. 1994, Menegaz et al. 2010, 2011, Rosso et al. 2011, Zanatta et al. 2011a, 2011b). VDR is also expressed in spermatocytes and spermatids of both rodents and humans (Blomberg Jensen et al. 2010a, 2010b, Zanatta et al. 2011c), but Sertoli cells are still considered to be the main VD target in the adult testis (Zanatta et al. 2011c). This assumption may not be entirely correct as testicular $V D R$ expression increases during puberty and the observed temporal correlation of increased VDR levels with testicular maturation suggests a better correlation to testicular function and spermatogenesis than to growth of the organ in vivo. If Sertoli cells were the main VD target, then the increased $V D R$ expression during puberty would imply that mature Sertoli cells have a higher VDR expression than the immature form, because Sertoli cells do not proliferate after puberty (Sharpe et al. 2003). Sertoli cells mature following stimulation with $\mathrm{FSH}$ and testosterone and cease their production of
anti-Müllerian hormone $(\mathrm{AMH})$ and estrogen (Sharpe et al. 2003). VDR epitopes were found in spermatogonia, Sertoli cells, and spermatocytes in testes from 9-monthold rats (Johnson et al. 1996). Accordingly, $V d r$ expression was shown in spermatogonia and Sertoli cells of 8-week-old mice (Hirai et al. 2009). However, VDR is absent or at best weakly expressed in few mature Sertoli cells in adult human testis samples (Blomberg Jensen et al. 2010b). VDR is expressed predominantly in adult germ cells, consistent with a high postpubertal VDR expression (Walters 1984, Osmundsen et al. 1989, Blomberg Jensen et al. 2010b) and the immunohistochemical (IHC) and immunocytochemical (ICC) studies using different VDR antibodies (Fig. 3; Johnson et al. 1996, Nangia et al. 1998, Corbett et al. 2006, Blomberg Jensen et al. 2010b). VDR was also detected in spermatogonia, spermatocytes, and Sertoli cells in roosters (Oliveira et al. 2008). A functional role of VDR in adult germ cells is underpinned by the presence of classical VD-regulated genes such as calbindin subtypes, aromatase (CYP19A1), and the transient receptor potential cation channel subfamily $\mathrm{V} 5$ (TRPV5) in both germ cells and spermatozoa (Kagi et al. 1988, Li et al. 2008, Carreau \& Hess 2010). It remains to be investigated whether VD affects proliferation and/or maturation of the immature Sertoli cells (including $\mathrm{AMH}$ production) and whether the VD-regulated genes that are transcribed during spermatogenesis subsequently influence gamete quality and function.

Some controversy exists regarding the presence of VDR in Leydig cells. It is an important question to answer as $V D R$ expression is a prerequisite for a direct effect of VD on systemic sex hormone production. Initially, VDR was found in similar amounts in isolated seminiferous tubules and interstitial tissue from adult rats, 


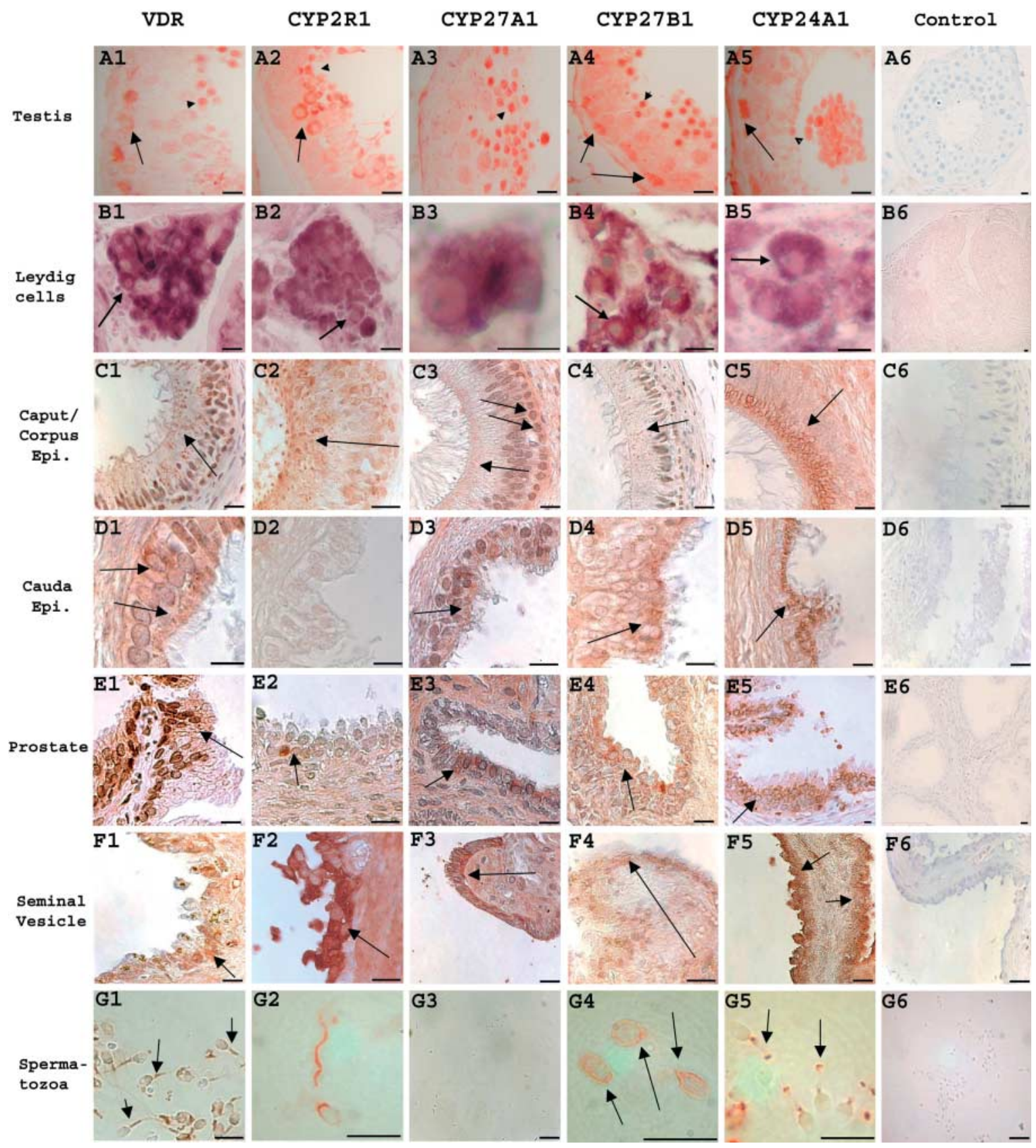

Figure 3 Expression of $V D R$ and vitamin $\mathrm{D}(\mathrm{VD})$ metabolizing enzymes in the human testis and male reproductive tract. (A1) VDR expression in the nucleus and cytoplasm (black arrow) of spermatogonia and in round spermatids (arrowhead). (A2) CYP2R1 expression in late spermatocytes (arrow) and round spermatids (arrowhead). (A3) CYP27A1 expression in round spermatids (arrowhead). (A4 and A5) Expression of CYP27B1 and CYP24A1 in spermatogonia (arrows) and round spermatids (arrowheads). (B1-5) Cytoplasmic expression of $V D R$ and all the metabolizing enzymes in Leydig cells. (C1-5) Black arrows indicate expression of $V D R$ and all the enzymes in the luminal vesicles, while double arrow points on expression of CYP27A1 in basal cells of caput/corpus epididymis. (D1-5) Abundant cytoplasmic expression of all investigated proteins except for CYP2R1 (D2) in cauda epididymis. (E1) Nuclear and cytoplasmic staining (arrow) in the epithelium of the prostate. (E2 and E3) A few cells (arrow) with a marked cytoplasmic expression of CYP2R1 and CYP27A1 in the prostate gland. (E4 and E5) Abundant expression of CYP27B1 and CYP24A1 in the prostate. (F1-5) A strong cytoplasmic expression of VDR and all the enzymes in the epithelium of the seminal vesicle. (G1) Expression of VDR in the midpiece (arrows). (G2) CYP2R1 expression in par, neck, and tail of ejaculated spermatozoa. (G3) No detectable expression of CYP27A1 in sperm.

(G4) Expression of CYP27B1 in par and neck of spermatozoa. (G5) Detection of CYP24A1 in the neck and at the annulus (arrows). (A6-G6) Negative controls, all except B6 and G6 counterstained with Mayer's. A6, B6, and G6 used monkey secondary antibody, while C6, D6, E6, and F6 used goat secondary antibody. Bar corresponds to $10 \mu \mathrm{m}$. Figure reproduced from Blomberg Jensen $\mathbf{M}$, Nielsen JE, Jorgensen A, Rajpert-de ME,

Kristensen DM, Jorgensen N, Skakkebaek NE, Juul A \& Leffers H 2010b Vitamin D receptor and vitamin D metabolizing enzymes are expressed in the human male reproductive tract. Human Reproduction 25 1303-1311. By permission of Oxford University Press. 
which imply that interstitial Leydig cells could be a likely target of VD (Levy et al. 1985a). This observation was questioned by later studies showing no VDR expression in Leydig cells from younger rodents (Merke et al. 1985, Stumpf et al. 1987) concluding that Sertoli and germ cells were the only testicular targets of VD. This was supported by an IHC investigation in rats showing VDR expression in the intratubular cells but not in Leydig cells (Johnson et al. 1996). However, these results are not in accordance with more recent IHC studies that all show detectable VDR expression in Leydig cells from humans, roosters, and mice (Oliveira et al. 2008, Hirai et al. 2009, Blomberg Jensen et al. 2010b). A recent study showed presence of $V d r$ mRNA in Leydig cells from rats, and the abundance of $V d r$ in the Leydig cells was comparable with the observed expression of $V d r$ in immature Sertoli cells (Zanatta et al. 2011a). The observed discrepancies between species could imply that $V D R$ expression is not conserved in the Leydig cells, although it is more likely to be due to differences in antibody specificity, method selection, age of the animals, etc. All IHC studies investigating protein expression in Leydig cells must be interpreted with caution as unspecific staining is a frequent finding when using commercially available antibodies and must be carefully optimized (Blomberg Jensen et al. 2010b). However, the presence of VDR mRNA in laser capture microdissected human Leydig cells revealed that $V D R$ messenger was present in isolated human Leydig cells (unpublished data). Antibody selection is vital and may also be influencing the results in a recent study that found no VDR expression in 80 human testis tissue samples using a nonclassified polyclonal VDR antibody (Bremmer et al. 2012). Only two VDR antibodies have been extensively validated and should be preferred for detection of VDR expression (Blomberg Jensen et al. 2010a, Wang et al. 2010). In conclusion, accumulating evidence suggest that VDR may be expressed in Leydig cells: i) co-localization of the VD metabolizing enzymes in human Leydig cells (Blomberg Jensen et al. 2010a), ii) expression of VD-regulated genes such as Calbindin and Calretinin, and iii) the observed transcriptional changes of these genes in Leydig cells in response to VD deficiency in chickens (Kagi et al. 1988, Strauss et al. 1994, Inpanbutr et al. 1996).

VDR is also expressed in human spermatozoa, and the subcellular location and function of VDR in human spermatozoa were recently reviewed (Blomberg Jensen $\&$ Dissing 2012). The presence of VDR in human sperm supported the observed $V D R$ expression during earlier stages of spermatogenesis as spermatozoa are virtually transcriptionally silent (Habib et al. 1990, Nangia et al. 1998, 2007, Corbett et al. 2006, Aquila et al. 2008, Blomberg Jensen et al. 2010b). VDR expression was observed in only a fraction of human spermatogonia and spermatocytes, while it was expressed in most spermatids (Blomberg Jensen et al. 2010b). The presence of VDR indicates that germ cells are exposed to VD progenitors and receptor binding can be achieved with $1,25(\mathrm{OH})_{2} \mathrm{D}_{3}$ concentrations below $1 \mathrm{nM}$. The observed binding affinity is in line with a previous study showing that $K_{\mathrm{d}}$ for VDR in the rat testis was $50 \mathrm{pM}$ (Gensure et al. 1991). Later in vitro studies also showed rapid effects when using similar $1,25(\mathrm{OH})_{2} \mathrm{D}_{3}$ concentrations (50 pM-1 nM) in both immature rodent Sertoli cells and ejaculated human spermatozoa (Blomberg Jensen et al. 2011, 2012, Menegaz et al. 2011, Zanatta et al. 2011c). Spermatozoa are highly compartmentalized cells and each compartment has different functions reflected by the spatial expression of several ion channels, transporters, etc., that are confined to a particular compartment (Publicover et al. 2007). All studies investigating $V D R$ expression in mature human spermatozoa showed $V D R$ expression in the postacrosomal part of the head, midpiece, and in the neck region (Corbett et al. 2006, Aquila et al. 2008, Blomberg Jensen et al. 2010b). Moreover, the reported pattern of $V D R$ expression was comparable with the expression of VD-binding protein in the postacrosomal region, neck, and midpiece of human spermatozoa (Yu et al. 1994). These findings were corroborated by a recent investigation of VD metabolizing enzymes in human spermatozoa, which showed co-localization of VDR with the VD metabolizing enzymes. Interestingly, VDR expression not only differed among men but also among spermatozoa from the same individual, and the receptor was mainly detected in the neck and head region of morphologically normal spermatozoa (Blomberg Jensen et al. 2010b). Human spermatozoa are a heterogeneous population of cells, and even in fertile men, a large proportion ( $>80 \%$ ) of spermatozoa are morphologically abnormal and only few are able to reach and fertilize the egg (Skakkebaek et al. 1994, Ikawa et al. 2010). The presence of VDR in a distinct subcellular location may thus depend on both optimal spermatogenesis and maturation as incomplete maturation could lead to aberrant localization and potentially malfunction of the receptor (Jimenez-Gonzalez et al. 2006, Blomberg Jensen et al. 2012). The presence of VDR in human spermatozoa supports that germ cells is the main site for VDR-mediated effects in adult testis and that VDR mediates nongenomic effects in ejaculated spermatozoa.

\section{Expression of the VD metabolizing enzymes}

VD is metabolized by the microsomal (CYP) enzymes situated in the endoplasmatic reticulum or mitochondria (Table 1). Gene mutations in humans and knockout mouse models have clarified which enzymes are involved in VD metabolism (Ponchon et al. 1969, Gray et al. 1972, Ohyama \& Yamasaki 2004, Prosser \& Jones 2004, Jones et al. 2011). The specificity of the CYP enzymes varies; some are very substrate specific, while others have multiple functions and substrates. Several 
Table 1 Vitamin D and serum levels of testosterone in men.

\begin{tabular}{|c|c|c|c|c|c|c|c|c|c|c|}
\hline No. & Design & $n$ & Age & Cohort & BMI & TT & FAI & LH & Comment & Reference \\
\hline 1 & Intervention & 8 & NA & $\begin{array}{l}\text { Hemodialysis } \\
\text { patients }\end{array}$ & NA & $\uparrow$ & NA & NA & $\begin{array}{l}1,25(\mathrm{OH})_{2} \mathrm{D}_{3} \text { treatment } \\
2-4 \text { months }\end{array}$ & Blumberg et al. (1980) \\
\hline 2 & Intervention & 3 & $<18$ & VD resistant rickets & NA & NA & NA & NA & Normal I hCG test & Hochberg et al. (1985) \\
\hline 3 & Case-control & 14 & $>50$ & Spinal-stenosis & NA & $\rightarrow$ & $\rightarrow$ & $\rightarrow$ & & Jackson et al. (1987) \\
\hline 4 & Intervention & 9 & 30 & Healthy & NA & $\rightarrow$ & NA & $\rightarrow$ & $\begin{array}{l}1,25(\mathrm{OH})_{2} \mathrm{D}_{3} \text { i.v. sensi- } \\
\text { tizes FSH secretion } \\
\text { to GNRH }\end{array}$ & Zofkova et al. (1996) \\
\hline 5 & Association & 187 & 46 & Healthy & NA & $\rightarrow$ & NA & NA & & Livshits et al. (1999) \\
\hline 6 & Association & 204 & 20 & Healthy & 22.6 & $\rightarrow$ & $\rightarrow$ & NA & & Valimaki et al. (2004) \\
\hline 7 & Association & 55 & 59 & Healthy & 29 & $\rightarrow$ & $\rightarrow$ & NA & & Chen et al. (2008) \\
\hline 8 & Association & 2229 & 67 & $\begin{array}{l}\text { Coronary } \\
\text { angiography }\end{array}$ & 27 & $\uparrow$ & $\uparrow$ & $\downarrow$ & & Wehr et al. (2010) \\
\hline 9 & Association & 307 & 20 & Healthy & 23 & $\rightarrow$ & $\downarrow$ & $\rightarrow$ & $\begin{array}{l}\text { Few men with VD } \\
\text { deficiency }\end{array}$ & $\begin{array}{l}\text { Ramlau-Hansen et al. } \\
\quad(2011)\end{array}$ \\
\hline 10 & RCT & 54 & 48 & Obese & 33 & $\rightarrow$ & $\uparrow$ & NA & $\begin{array}{l}\text { Conclusion limited } \\
\text { by study design }\end{array}$ & Pilz et al. (2011) \\
\hline 11 & Association & 1115 & 48 & Healthy & 28 & $\rightarrow$ & $\rightarrow$ & NA & & Ceglia et al. (2011) \\
\hline 12 & Association & 1362 & 66 & Healthy & 26 & $\uparrow$ & $\uparrow$ & NA & & Nimptsch et al. (2012) \\
\hline 13 & Association & 3369 & 59 & Healthy & 27 & $\uparrow$ & $\uparrow$ & $\downarrow$ & $\begin{array}{l}\text { Associations not signi- } \\
\text { ficant after adjust- } \\
\text { ment for confounders }\end{array}$ & Lee et al. (2012) \\
\hline
\end{tabular}

Thirteen human studies investigating the relationship between serum testosterone and vitamin D were evaluated. This table summarizes study design, cohort size and characteristics, main results, and important additional information. N, cohort size; BMI, body mass index; TT, total testosterone; FAI, free androgen index; $\rightarrow$, no change; $\uparrow$, positively associated; $\downarrow$, negatively associated; NA, not available.

CYP enzymes are capable of mediating 25-hydroxylation of cholecalciferol, but CYP2R1 is recognized as the most important 25-hydroxylase probably supported by CYP27A1 (Ohyama \& Yamasaki 2004). This was convincingly demonstrated in vitro, where cellular overexpression of CYP2R1 caused transcriptional activation of $V D R$ following addition of cholecalciferol. The resultant secosteroid product of CYP2R1 activation proved to be $25-\mathrm{OHD}_{3}$ and co-expression of CYP2R1 with $1 \alpha$-hydroxylase (CYP27B1) elicited additive activation, whereas co-expression with 24-hydroxylase (CYP24A1) caused inactivation (Cheng et al. 2003). Moreover, a patient homozygous for a transition mutation in exon 2 of the CYP2R1 gene had low serum levels of $25-\mathrm{OHD}_{3}$ thereby supporting CYP2R1 candidacy as the microsomal VD 25-hydroxylase. Conversely, mice with a disrupted Cyp27a1 gene showed no significant change in serum $25-\mathrm{OHD}_{3}$ and $1,25(\mathrm{OH})_{2} \mathrm{D}_{3}$ (Rosen et al. 1998). CYP2R1 mRNA is expressed in various tissues, but it is predominantly found in the liver and testes of both mice and humans, indicating a role in activation of cholecalciferol not only in the liver but also in the male gonad (Choudhary et al. 2003, 2005, Bieche et al. 2007). CYP27B1 is the only known $1 \alpha$-hydroxylase (Gray et al. 1972, Ohyama \& Yamasaki 2004) and strong evidence that it is mandatory for the formation of $1,25(\mathrm{OH})_{2} \mathrm{D}_{3}$ came from observations in patients with kidney failure, children with inactivating mutations in the CYP27B1 gene, and Cyp27b1 knockout mice (Ritz et al. 1979, Panda et al. 2001). On the other hand, CYP24A1 was confirmed as the VD inactivating enzyme by inactivating mutations that caused infantile hypercalcemia due to lack of $1,25(\mathrm{OH})_{2} \mathrm{D}_{3}$ degradation and further supported by knockout models (St-Arnaud 1999,
St-Arnaud et al. 2000, Dauber et al. 2011, Ji \& Shen 2011, Streeten et al. 2011).

Expression of VD metabolizing enzymes has been reported in several tissues of both animals and humans, with the highest concentrations of CYP2R1, CYP27B1, and CYP24A1 mRNA in kidney specimens followed by testis (Akeno et al. 1997, Cheng et al. 2003). Our own studies on human testis samples revealed that VDR and all the VD metabolizing enzymes were co-expressed in a subset of spermatocytes, all spermatids, most Leydig cells, and a fraction of ejaculated spermatozoa, while only VDR, CYP27B1, and CYP24A1 were expressed in spermatogonia (Fig. 3; Blomberg Jensen et al. 2010b). Interestingly, VDR and all the VD metabolizing enzymes co-localized in the postacrosomal region of the head and in the neck of mature human spermatozoa, but CYP24A1 was distinctly expressed at the sperm annulus, together with VDR (Blomberg Jensen et al. 2010b, 2012). VDR and the VD metabolizing enzymes, including CYP24A1, were expressed in a higher fraction of spermatozoa from normal men compared with sperm from infertile men, suggesting a possible relationship between VD and high semen quality (Blomberg Jensen et al. 2012). In particular, CYP24A1 may be suitable marker for semen quality, because this enzyme is a strong indicator for the presence of activated $V D R$ and the expression at the sperm annulus is easy to recognize (Fig. 4; Blomberg Jensen et al. 2012). CYP24A1 may also be a marker of adequate VD stimulation during spermatogenesis as its presence in transcriptionally inactive spermatozoa depends on the concentration of $1,25(\mathrm{OH})_{2} \mathrm{D}_{3}$ that induces transcription through binding to VDRE's in the CYP24A1 promoter region (Haussler et al. 2011). CYP24A1 expression not only distinguished 


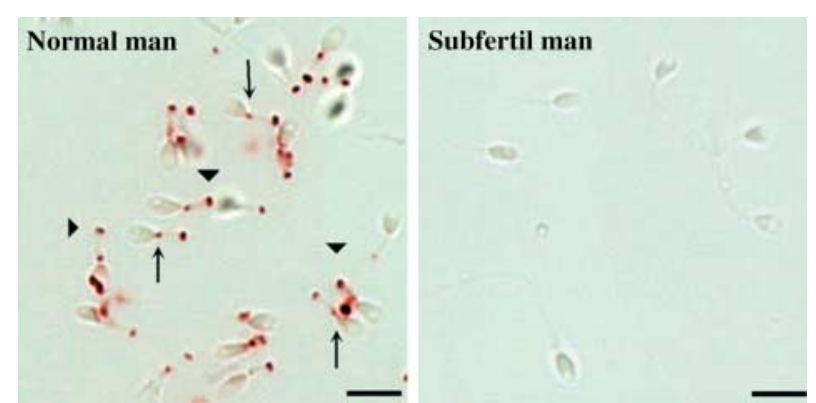

Figure 4 CYP24A1 expression in human spermatozoa. Semen sample from a man from the general population with sperm concentration: $123 \mathrm{million} / \mathrm{ml}$ and $87 \%$ motile sperm. $85 \%$ of his spermatozoa are expressing CYP24A1 at the annulus (left). Semen sample from a man part of an infertile couple with sperm concentration: 6 million $/ \mathrm{ml}$ and $50 \%$ motile sperm. This man has $0 \%$ expressing CYP24A 1 at the annulus (right). Arrowhead indicates annulus and arrows indicate expression at the neck. Bar corresponds to $10 \mu \mathrm{m}$. Figure reproduced from Blomberg Jensen $M$, Jørgensen $A$, Nielsen JE, Leffers $\mathbf{H}$, Andersen AN, Skakkebaek NE, Juul A, Rajpert-De-Meyts E \& Jørgensen N 2012 Expression of the vitamin D metabolizing enzyme CYP24A1 at the annulus of human spermatozoa may serve as a novel marker of semen quality. International Journal of Andrology. By permission of John Wiley and Sons.

spermatozoa from normal and infertile men with high specificity but was also positively associated with a number of semen quality variables (sperm count, concentration, motility, and morphology), thus supporting the use of CYP24A1 as a marker of semen quality (Blomberg Jensen et al. 2012).

The presence of VDR and the VD metabolizing enzymes in the testis and epididymis suggests that VD is metabolized locally (Fig. 3), which is in line with earlier studies that have shown metabolism of VD in the male reproductive organs following s.c. injections of tritiated $25-\mathrm{OHD}_{3}$ in mice. The highest concentration of the VD progenitor was found in the kidney, followed by epididymis, prostate, testis, and seminal vesicle, and the concentrations were augmented by intravenous route of dosing (Kidroni et al. 1983). A recent paper reported that CYP2R1 was exclusively expressed in the Leydig cells and suggested that testes were important not only for local VD metabolism but also for systemic activation of VD (Foresta et al. 2010, 2011). These authors observed that both serum levels of $25-\mathrm{OHD}_{3}$ and testicular expression levels of CYP2R1 were lower in men with oligozoospermia or Sertoli-cell-only syndrome (SCO) compared with normal men and explained this by low expression of CYP2R1 in the Leydig cells (Foresta et al. 2011). However, from the pictures presented in the manuscript (Foresta et al. 2011), it is evident that CYP2R1 is also expressed in the germ cells, in accordance with our previous study using the same CYP2R1 antibody (Blomberg Jensen et al. 2010a). Thus, the low CYP2R1 content in the testis from oligozoospermic or SCO men could be due to few or no germ cells and not due to an aberrant CYP2R1 expression in the Leydig cells.

\section{VD regulates biosynthesis of estradiol and testosterone}

Numerous studies investigated the putative physiological relationship between circulating levels of $25 \mathrm{OHD}_{3} / 1,25(\mathrm{OH})_{2} \mathrm{D}$, the activity of VDR and VD metabolizing enzymes, and serum testosterone and estradiol levels in both animals and humans (Tanaka et al. 1976, Hyldstrup et al. 1984, Small et al. 1984, Hochberg et al. 1985, Krabbe et al. 1986, Sonnenberg et al. 1986, Hagenfeldt et al. 1992, Morley et al. 1993, Inpanbutr et al. 1996, Zofkova \& Kancheva 1996, Otremski et al. 1997, Rapado et al. 1999, Kinuta et al. 2000, van Abel et al. 2002, Braga et al. 2002, Van Cromphaut et al. 2003, Echchgadda et al. 2004, Valimaki et al. 2004, Kastelan et al. 2009, Fleet \& Schoch 2010, Krishnan et al. 2010a, 2010b, Meng et al. 2010, Pilz et al. 2011, Ramlau-Hansen et al. 2010, Wehr et al. 2010, Ceglia et al. 2011, Foresta et al. 2011, Lundqvist et al. 2011, Lee et al. 2012). It has been shown that estrogen promotes the two-step activation of cholecalciferol to $1,25(\mathrm{OH})_{2} \mathrm{D}_{3}$ and reinforces a positive effect on calcium homeostasis through a direct stimulatory effect on intestinal calcium absorption. Testosterone is also a stimulator of calcium absorption in prepubertal boys, but studies in mice show that androgens increase calcium excretion by inhibiting expression of renal calcium transport proteins (Fleet \& Schoch 2010, Hsu et al. 2010).

Regulation of aromatase (CYP19A1) and estrogen production by VD has been extensively studied in tissueand cell lines from breast, adipose tissue, bone, and gonads (Krishnan et al. 2010a, 2010b). $1,25(\mathrm{OH})_{2} \mathrm{D}_{3}$ is a known regulator of aromatase expression (Bouillon et al. 2008, Haussler et al. 2011), but the effect is tissue specific due to activity of different promoters $(1.3,1.4$,II) in various tissues. $1,25(\mathrm{OH})_{2} \mathrm{D}_{3}$ mediates transcriptional repression of aromatase expression in breast, in contrast to a modest gonadal induction (ovary) and a high induction in bone (Krishnan et al. 2010b). The proposed tissue-specific regulation is in line with an earlier study showing lower aromatase expression in testis and epididymis concomitant with lower serum estrogen and elevated gonadotropins in $V d r \mathrm{KO}$ mice compared with wild-type animals (Kinuta et al. 2000). Interestingly, the reduced serum estrogen level was reversible following calcium supplementation, indicating that at least part of the impaired gonadal aromatase expression was due to hypocalcemia. In contrast, the elevated LH level persisted and may therefore depend on additional factors besides calcium imbalance (Kinuta et al. 2000). A recent study supported the tissue-specific $1,25(\mathrm{OH})_{2} \mathrm{D}_{3}$-mediated regulation of aromatase expression using three different cell lines. Besides tissue-specific regulation of aromatase, they also found that $1,25(\mathrm{OH})_{2} \mathrm{D}_{3}$ induced androgen production in 
breast and prostate but caused an opposite effect in adrenal cells (Lundqvist et al. 2011).

It is noteworthy that the observed in vitro effects seemed less pronounced in vivo as VD-deficient chickens had higher (although not significantly) serum testosterone levels than controls, despite that VD deficiency caused low calbindin expression in the Leydig cells (Inpanbutr et al. 1996). However, another study found low serum testosterone in VD-deficient rats, which increased to normal values following supplementation of $1,25(\mathrm{OH})_{2} \mathrm{D}_{3}$ (Sonnenberg et al. 1986). Importantly, a small human study conducted on boys younger than 18 years with VD-resistant rickets (no functional VDR) showed that the sensitivity to LH was not affected by $\mathrm{VD}$, as serum testosterone concentration after hCG stimulation (hCG test) was normal (Hochberg et al. 1985). Several human studies (Table 1) have investigated the relationship between $25-\mathrm{OHD}_{3}$ or $1,25(\mathrm{OH})_{2} \mathrm{D}_{3}$ and testosterone production. A direct comparison of these selected studies is not advisable because the cohorts differ greatly in size, age, comorbidities, median $25-\mathrm{OHD}_{3}$ level, and the use of relevant confounders such as time of blood sampling, serum LH, calcium, etc. The positive associations between serum $25-\mathrm{OHD}_{3}$ and testosterone/free androgen index (FAI) are mainly reported in men above 40 years of age, with a median BMI above 25 and presence of comorbidities such as metabolic syndrome, diabetes, or cardiovascular disease. By contrast, in younger healthy men, serum levels of $25-\mathrm{OHD}_{3}$ were either not associated or negatively associated with testosterone and FAI, while serum $25-\mathrm{OHD}_{3}$ was positively associated with SHBG (Valimaki et al. 2004, Ramlau-Hansen et al. 2011). Other studies have shown that both serum $25-\mathrm{OHD}_{3}$ and testosterone levels decline with age, while gonadotropins and SHBG increase. The age-related alterations may be of clinical importance and probably partly responsible for the increased risk of osteoporosis with age (van Abel et al. 2006, Giovannucci et al. 2006, Kaplan et al. 2006, Bischoff-Ferrari 2008, van Schoor et al. 2008, Ross 2011, Lee et al. 2012). Simple associations do not prove causality but may rather reflect other imbalances as indicated in a large study examining 1340 men aged 76 years or older. Here, total testosterone inversely correlated with serum phosphorous, while calcium levels were positively correlated with PTH (Meng et al. 2010).

Accumulating evidence suggests a complex interplay between bone, gonadal function, calcium absorption and excretion, glucose metabolism, and pituitary function (Fukumoto \& Martin 2009, Hwang et al. 2011, Oury et al. 2011, Pi et al. 2011): sex hormones regulate calcium absorption, bone formation, and insulin production; VD stimulates calcium absorption, bone formation, estrogen and insulin production; and bone markers such as osteocalcin stimulate testosterone and insulin production. The complicated relationship must be taken into account when investigating associations between VD and sex hormones, and it is not advisable to extrapolate from simple associations between two factors, because the disturbance or imbalance in a selected organ may be fully or partly compensated by various mechanisms; for instance, low serum VD levels by calcium mobilization due to elevated PTH secretion. Such compensation may be decreasing with age, which could explain the positive associations reported in older men with comorbidities, but further studies are needed to clarify this. New association studies should therefore address the relationship between sex hormones and VD levels by including additional factors such as calcium, PTH, phosphate, LH, estrogen, and optimally also BMD, osteocalcin, IGF1, FGF23, body fat percentage, and glucose metabolism to determine causal associations that can be subsequently used as endpoints for validation in randomized clinical trials (RCT).

Most of the association studies investigating VD and testosterone stratified their cohort in tertiles or quartiles. This can be appropriate, but the conclusions drawn may be limited, in particular when $25-\mathrm{OHD}_{3}$ serum level is the explanatory variable. VD has the highest impact on most organs in the concentration range from undetectable to $50 \mathrm{nM}(20 \mathrm{ng} / \mathrm{ml})$, while most of the effects are stable when serum 25-OHD 3 levels exceed 75-100 nM (Dawson-Hughes et al. 2005, Lips 2006, Lips et al. 2010). Thus, the clinical relevance is reduced when the median VD concentration in the cohort is high, as an increase in serum 25- $\mathrm{OHD}_{3}$ level from 80 to $90 \mathrm{nM}$ is unlikely to have any major physiological effect. Recently, a large association study showed a dose-response relationship between $25-\mathrm{OHD}_{3}$ and testosterone. It was comparable to the effects observed between VD and PTH secretion or calcium absorption, because it was strong in the lower range of the serum $25-\mathrm{OHD}_{3}$ scale and leveled off above 50-80 nM (Nimptsch et al. 2012). This could be due to a direct effect of VD progenitors on the Leydig cells, although it could also be secondary to changes in calcium homeostasis caused by VD deficiency (Bouillon et al. 2008). Unfortunately, this study was limited by the low proportion of VD-deficient men, thus precluding investigation of associations at the very low end of $25-\mathrm{OHD}_{3}$ levels $(<25 \mathrm{nmol} / \mathrm{l})$, where the effect presumably would be larger. Moreover, most of the studies reporting a positive association between VD and total testosterone/FAI are limited by an age effect (Table 1). Men with high $25-\mathrm{OHD}_{3}$ serum concentrations are generally younger and have a higher testosterone level than men with low $25-\mathrm{OHD}_{3}$. The age difference between each quartile is more than 1 year in the large association study investigating more than 2000 men referred for coronary angiography, and a similar age trend was found from the lowest to the highest VD quintile in a recent association study (Wehr et al. 2010, Nimptsch et al. 2012). Although most studies 
adjust their analyses for age, they are not adjusted for the frequency of comorbidities such as impaired bone health, glucose metabolism, kidney function, calcium absorption, etc., that follows with increasing age. This concern was corroborated by a recent association study including more than 3000 elderly men (Lee et al. 2012). The authors found the same positive associations between $25-\mathrm{OHD}_{3}$ serum level and testosterone/FAI, but after adjusting for health and lifestyle factors, no significant associations were observed between $25-\mathrm{OHD}_{3}$ and any of the reproductive hormones. However, the putative positive effect of VD on testosterone production was supported by a small RCT, which showed increasing testosterone following VD supplementation (average 48 years). The clinical value is limited by the design of the study as they mainly tested the effect of weight loss. Moreover, the causal factor is not obvious despite that the increase in testosterone was $2.7 \mathrm{nM}$ in cholecalciferol-treated men vs $0.9 \mathrm{nM}$ in the control group (Pilz et al. 2011). In conclusion, sufficient data exist to claim that VD is a strong regulator of aromatase expression and may be involved in regulation of steroidogenesis in human Leydig cells, but so far, there is not enough evidence for a stimulatory effect of VD on testicular testosterone production.

\section{VD and reproductive function: lessons from knockout mice}

Dent \& Harris (1956) suggested that hereditary rickets (either no functional VDR or CYP27B1) in humans results in diminished fertility. Still, it has not yet been proven that VD is necessary for male reproductive function. Evaluating the reproductive effects of VD is complicated as impaired performance due to low serum $25-\mathrm{OHD}_{3}$ or diminished testicular VD metabolism is at least partly compensated by several other factors. Especially, the strong association between VD deficiency and hypocalcemia should always be considered when evaluating data from animal models or human studies (Sood et al. 1995, Lips 2006, Bouillon et al. 2008). Studies on $\mathrm{KO}$ mice provide strong evidence for beneficial effects of VD in male reproduction (Bouillon et al. 2008). Yoshizawa et al. (1997) showed that both male and female mice with homozygous $V d r$ deletion (Tokyo strain) were infertile. Intriguingly, two other $V d r$ KO strains were not infertile but presented with impaired fertility and low litter size (Johnson \& DeLuca 2001, Kovacs et al. 2005, Bouillon et al. 2008). In the Vdr KO mice Tokyo strain, testes histology appeared grossly normal unlike the female counterpart, which is in accordance with the gonadal phenotype in humans with VD-dependent rickets type II (Malloy et al. 1990, Hawa et al. 1996). The initial normal testis histology of $V d r \mathrm{KO}$ mice was also corroborated by the phenotype observed following targeted ablation of the 25-hydroxyvitamin-D-1 $\alpha$-hydroxylase (Cyp27b1), which not only caused infertility but also resulted in grossly normal testis histology (Panda et al. 2001). Cyp24a1 KO mice develop hypercalcemia, and $50 \%$ of the homozygous mutants die before 3 weeks of age probably due to severe hypercalcemia. The animals surviving to adulthood are fertile despite deposition of mineral in several organs of the mutant mice (Masuda et al. 2005). A more detailed evaluation of testis histology and reproductive phenotype were also performed in males from the Tokyo $V d r$ $\mathrm{KO}$ strain, revealing an increased luminal diameter and shortened epithelial width in some tubules from 10-week-old $V d r \mathrm{KO}$ mice compared with controls (Kinuta et al. 2000). The increase in luminal size was explained by fluid accumulation caused by diminished water reabsorption in rete testis and the proximal part of epididymis. Thereby suggesting imbalance in estrogen, as water reabsorption in this part of the male reproductive tract is mainly regulated by estrogen (Hess et al. 1997). Indeed, aromatase (CYP19A1) expression and activity were reduced in epididymis and testis from $V d r \mathrm{KO}$ mice concomitant with a $40 \%$ decline in serum estrogen levels leading to hypergonadotropic hypogonadism with elevated FSH (twofold) and LH (eightfold) compared with wild type (Kinuta et al. 2000). Interestingly, FSH and estradiol but not LH levels normalized following calcium supplementation. This indicates a direct effect of VD and not solely impairment of reproductive performance due to hypocalcemia (Kinuta et al. 2000). VD regulates aromatase expression in a tissue-selective manner, and it is possible that elevated $\mathrm{LH}$ is due to diminished transformation of testosterone to estrogen in the hypothalamic area/pituitary gland. Testosterone concentration is 1000 times higher in males compared with females, and thus mainly responsible for feedback inhibition despite its dependency on local aromatization in the hypothalamic region/pituitary gland (Pitteloud et al. 2008).

The $V d r$ KO mice presented with a $50 \%$ reduction in sperm concentration in addition to a marked inhibitory effect on sperm motility that fell from 50 to $60 \%$ in wild type to $15 \%$ in the $V d r \mathrm{KO}$. The decline in sperm motility was aggravated over time and only $1 \%$ motile sperm was found after 10 weeks, while spermatogenesis was rarely detected in 15-week-old Vdr KO mice (Kinuta et al. 2000). Unfortunately, there exists no information about testosterone concentration in $V d r \mathrm{KO}$ mice. However, estradiol supplementation corrected the reproductive phenotype, and it is therefore unlikely that testosterone level is severely impaired (Kinuta et al. 2000). Other studies have associated VD with reproductive performance in females, and female $V d r \mathrm{KO}$ mice regained fertility following calcium supplements (Johnson \& DeLuca 2001). Even though $V d r$ KO mice regained the ability to conceive (hard endpoint) following 
calcium supplementation, several important reproductive questions remain such as the effect on time to pregnancy (TTP), semen quality variables, litter size, healthy pregnancy rate, rate of abortions, etc., in order to determine whether VD is important for male reproductive function.

\section{VD deficiency and reproductive function}

Some of the reproductive issues were addressed several years ago by two studies investigating the effect of VD deficiency on reproductive function in rodents. Kwiecinski et al. (1989) showed that VD-deficient males were capable of reproduction, but successful mating (evaluated by the presence of sperm in the female vaginal tract) between a healthy female and a VD-deficient male was reduced by $45 \%$ compared with VD replete males. Moreover, fertility (determined as successful pregnancies in sperm-positive females) was reduced by $73 \%$ in litters from VD-deficient male inseminations compared with litters from females inseminated by VD replete males (Kwiecinski et al. 1989). Three years later, the same group questioned the direct effect of VD on male reproduction and concluded that the impaired fertility could be restored by calcium supplements alone (Uhland et al. 1992). This follow-up study was well conducted but compromised by some methodological problems. When re-analyzing their data with an andrological perspective, the data can be interpreted differently and changing the original conclusions made by the authors (Tables 2 and 3; Uhland et al. 1992). The chance of successful pregnancy in mammals depends on several factors besides $25-\mathrm{OHD}_{3}$ and serum calcium level. In the study by Uhland et al. (1992), each male rat was not always mated with only one female rat, and the mating period varied from 1 to

Table 2 Effect of intervention on reproductive variables in VD-deficient rats.

\begin{tabular}{|c|c|c|c|c|c|}
\hline \multirow{3}{*}{$\frac{\text { Variable }}{1 . \text { Intervention }}$} & \multicolumn{2}{|c|}{ Pretreatment } & \multicolumn{3}{|c|}{ Posttreatment } \\
\hline & \multirow{2}{*}{$\begin{array}{l}\text { VD replete } \\
2 \mu \mathrm{g} \mathrm{D}_{3} \\
\text { i.p./week }\end{array}$} & \multirow{2}{*}{$\begin{array}{l}\text { VD deficiency } \\
\text { None }\end{array}$} & \multirow{2}{*}{$\begin{array}{c}\text { VD replete } \\
\text { UA } \mu g D_{3} \\
\text { orally }\end{array}$} & \multicolumn{2}{|c|}{ VD deficient treated for 3 weeks } \\
\hline & & & & $\begin{array}{l}2 \mu \mathrm{g} \mathrm{D}_{3} \\
\text { i.p./week }\end{array}$ & $\begin{array}{l}100 \mathrm{ng} 1,25 \mathrm{D}_{3} \\
\text { i.p./day }\end{array}$ \\
\hline 2. Start s-calcium (mM) & 2.5 & 1.3 & 2.5 & 1.8 & 1.8 \\
\hline 3. End s-calcium (mM) & ND & ND & 2.5 & 2.6 & 2.7 \\
\hline 4. Males $(\mathrm{N})$ & 40 & 66 & 15 & 17 & 17 \\
\hline 5. Male:female ratio & 0.82 & 0.78 & 0.79 & 0.68 & 0.71 \\
\hline 6. Female index & 1.00 & 1.05 & 1.00 & 1.16 & 1.11 \\
\hline 7. Days mated & 212 & 499 & 74 & 93 & 109 \\
\hline 8. Sperm-positive smears & 42 & 55 & 15 & 22 & 24 \\
\hline 9. Positive sperm smear/day & 0.20 & 0.11 & 0.20 & 0.24 & 0.22 \\
\hline 10. Male activity & 0.90 & 0.73 & 0.87 & 0.94 & 1.00 \\
\hline 11. Females giving birth to normal litters $(\mathrm{N})$ & 32 & 20 & 8 & 11 & 8 \\
\hline $\begin{array}{l}\text { 12. Females giving birth to normal litters } \\
\text { adjusted female index }\end{array}$ & 32 & 19 & 8 & 10 & 7 \\
\hline 13. Pregnancies per day & 0.15 & 0.04 & 0.11 & 0.12 & 0.07 \\
\hline $\begin{array}{l}\text { 14. Pregnancies per day adjusted for female } \\
\text { index }\end{array}$ & 0.15 & 0.04 & 0.11 & 0.10 & 0.07 \\
\hline $\begin{array}{l}\text { 15. Pregnancies per day adjusted for female } \\
\text { index and }(\mathrm{N}) \text { males }\end{array}$ & 0.15 & 0.02 & 0.11 & 0.09 & 0.06 \\
\hline 16. TTP for healthy pregnancy & 7 & 25 & 9 & 8 & 14 \\
\hline $\begin{array}{l}\text { 17. TTP for healthy pregnancy adjusted } \\
\text { male:female ratio }\end{array}$ & 7 & 26 & 9 & 10 & 15 \\
\hline $\begin{array}{l}\text { 18. TTP for healthy pregnancy adjusted } \\
\text { male:female ratio and }(\mathrm{N}) \text { males }\end{array}$ & 7 & 42.9 & 9 & 11.3 & 17 \\
\hline $\begin{array}{l}\text { 19. Fraction healthy pregnancies/sperm } \\
\text { positive }\end{array}$ & 0.76 & 0.36 & 0.53 & 0.51 & 0.33 \\
\hline $\begin{array}{l}\text { 20. Fraction healthy pregnancies/sperm } \\
\text { positive adjusted M:F ratio }\end{array}$ & 0.76 & 0.35 & 0.53 & 0.44 & 0.30 \\
\hline $\begin{array}{l}\text { 21. Fraction healthy pregnancies/sperm } \\
\text { positive per day }\end{array}$ & 0.0036 & 0.0017 & 0.0025 & 0.0024 & 0.0016 \\
\hline $\begin{array}{l}\text { 22. Fraction healthy pregnancies/sperm } \\
\text { positive adjusted M:F ratio per day }\end{array}$ & 0.0036 & 0.0016 & 0.0025 & 0.0021 & 0.0014 \\
\hline 23. Mean litter size & 12.6 & 10.4 & 12.6 & 10.7 & 10.4 \\
\hline
\end{tabular}

Data obtained and recalculated from Uhland et al. (1992). 1. Supplementation with either with $\mathrm{D}_{3}$.or $1,25(\mathrm{OH})_{2} \mathrm{D}_{3}\left(1,25 \mathrm{D}_{3}\right) .2$ and 3 . Serum levels of calcium. 4. Number of male animals in each group. 5. Number of females mated with each male. 6 . Number of females per male, VD replete animals set as reference. 7. Total days of allowed mating. 8. Presence of sperm in the vagina is considered successful mating. 9. Proportion of successful matings per day. 10. Percentage of active males. 11. Number of females giving birth to healthy litters. 12. Number of females giving birth to healthy litters adjusted for female index. 13. Number of pregnancies for each group per day of allowed mating. 14. Number of pregnancies per day of allowed mating adjusted for female index. 15. Proportion of pregnancies per day of allowed mating adjusted for number of animals. 16. TTP: time to pregnancy for the whole group (dependency on N). 17. TTP adjusted for female index. 18. TTP adjusted for female index and number of males (VD replete males $=1$ ) as the number of pregnancies in the group depends on the total number of couples. 19-21. Proportion of healthy pregnancies after successful mating is an indicator of semen quality for the whole group (dependent on duration of allowed mating). This variable may serve as an indicator for semen quality after the adjustment for time of allowed mating (fertility potential). UA, unavailable, ND, not determined. 
Table 3 Reproductive outcome after calcium supplementation of vitamin D-deficient male rats.

\begin{tabular}{|c|c|c|c|}
\hline Variable & $\begin{array}{l}\text { VD deficiency } \\
\text { hypocalcemic }\end{array}$ & $\begin{array}{l}\text { VD deficiency } \\
\text { normocalcemic }\end{array}$ & VD replete \\
\hline 1. Cholecalciferol orally three times weekly $(\mu \mathrm{g})$ & None & None & 1.875 \\
\hline 2. Start s-calcium $(\mathrm{mM})$ & 1.3 & 2.2 & ND \\
\hline 3. End s-calcium (mM) & 1.4 & 2.2 & 3.0 \\
\hline 4. $\mathrm{s}-25-\mathrm{OHD}_{3}(\mathrm{nM})$ & ND & ND & $21-26$ \\
\hline 5. $\mathrm{s}-1,25(\mathrm{OH})_{2} \mathrm{D}_{3}(\mathrm{pM})$ & 1.0 & 17.0 & $53-75$ \\
\hline 6. Diet & Purified & High calcium & High calcium \\
\hline 7. Animals (N) & 43 & $37^{\circ}$ & 16 \\
\hline 8. Male:female ratio & 1 & 1 & 1 \\
\hline 9. Days mated & 121 & 102 & 44 \\
\hline 10. Days mated/animal & 2.88 & 2.76 & 2.75 \\
\hline 11. Sperm-positive smears (successful mating) & 42 & 36 & 16 \\
\hline 12. Male activity & $98 \%$ & $97 \%$ & $100 \%$ \\
\hline 13. Sperm-positive smears/day & 0.347 & 0.353 & 0.364 \\
\hline 14. Females giving birth to normal litters $(\mathrm{N})$ & 21 & 30 & 10 \\
\hline 15. Pregnancies per day & 0.17 & 0.29 & 0.23 \\
\hline 16. Proportion of males responsible for pregnancy/day & $0.4 \%$ & $0.8 \%$ & $1.4 \%$ \\
\hline 17. TTP healthy pregnancies (days) & 5.8 & 3.4 & 4.4 \\
\hline 18. TTP healthy pregnancies (days) adjusted $(\mathrm{N})$ males & 15.6 & 7.7 & 4.4 \\
\hline 19. Fraction healthy pregnancies/sperm-positive smear & 0.5 & 0.8 & 0.6 \\
\hline 20. Fraction healthy pregnancies/sperm positive/day & $0.4 \%$ & $0.8 \%$ & $1.4 \%$ \\
\hline 21. Mean litter size & 13.0 & 13.5 & 15.1 \\
\hline
\end{tabular}

Data obtained and recalculated from Uhland et al. (1992). 1. Only VD replete animals received oral supplements with $\mathrm{D}_{3}$. 2-5. Serum levels of VD progenitors and calcium. 6. Type of diet. 7. Number of animals in each group. 8. Number of females mated with each male. 9. Total days of allowed mating. 10. Days each male is allowed to mate. 11. Presence of sperm in the vagina is considered successful mating. 12. Proportion of males able to produce a positive smear during the days of allowed mating. 13. Successful mating per day. 14. Number of females giving birth to healthy litters. 15. Number of pregnancies for each group per day of allowed mating. 16. Proportion of pregnancies per day of allowed mating adjusted for number of animals. 17. TTP: time to pregnancy for the whole group (dependency on N). 18. TTP adjusted to number of males $(V D$ replete males $=1)$ as the number of pregnancies in the group depends on the total number of couples. 19. Proportion of healthy pregnancies after successful mating is an indicator of semen quality for the whole group (dependent on the duration of allowed mating). 20. This variable may serve as an indicator for semen quality after the adjustment for time of allowed mating (fertility potential).

10 days. This will obviously influence the results and the data should be corrected for number of female per male (male/female ratio) and the number of days they were allowed to mate as longer mating period increases the chances for pregnancy. The frequency of mating is also important because the chance of spermatozoa being present in the female reproductive tract at the time of ovulation increases with frequent mating. Moreover, infertility in humans is not defined as a definite inability to conceive but it is usually defined as an inability to conceive during 12 months of contraceptive-free intercourse (WHO 2010). Twelve months is the lower reference limit for TTP, and TTP is a good indicator for fertility potential because it depends on semen quality variables, oocyte quality, and regular ovulation (Bonde et al. 1998).

Based on these assumptions, the data published by Uhland et al. (1992) were re-calculated to compare the different treatments with the above-mentioned factors taken into account. From Table 2, it is obvious that VD-deficient animals are responsible for fewer spermpositive smears per day of allowed mating and exposed to fewer females than the VD replete animals. TTP was longer in the VD-deficient groups especially after adjusting to the number of animals in each group. The presence of sperm in the vagina is not sufficient to secure pregnancy. After mating, the spermatozoa must swim up, bind, and fertilize the oocyte in the fallopian tube before fertilization occur (Ikawa et al. 2010), and the frequency of healthy pregnancies/successful mating would be an indicator of sperm function. None of the VD-deficient males achieved a reproductive level that was comparable with the male rats with high VD status from the start regardless to the choice of treatment. The VD replete group had the highest chance of healthy pregnancies and logically thereof the highest litter size. This indicates that the length and type of VD supplementation may be important and should be considered before treatment of VD deficiency. Supplementation with $1,25(\mathrm{OH})_{2} \mathrm{D}_{3}$ did not improve male fertility markedly compared with the untreated VD-deficient males despite the increase in serum calcium. The diminished effect of $1,25(\mathrm{OH})_{2} \mathrm{D}_{3}$ supplementation indicates that local VD metabolism is important and that testicular VD metabolism may be regulated by different factors besides circulating progenitors of VD (Blomberg Jensen et al. 2012). Table 3 shows the fertility potential of VD-deficient male rats with hypocalcemia and normocalcemia. Surprisingly, TTP and the fraction of healthy pregnancies/mating per day (healthy pregnancy) were not fully reversible after normalization of serum calcium in the VD-deficient rats. VD replete males had a threefold higher chance of healthy pregnancies compared with VD-deficient rats with hypocalcemia and an almost twofold higher chance than VD-deficient 
rats with normocalcemia. This indicates that VD is important for semen quality, and the diminished effect caused by VD deficiency cannot be reversed by calcium supplements. This observation is supported by the difference in TTP and litter size. VD-deficient normocalcemic rats resembled the hypocalcemic VD-deficient rats and litter size remained lower in both groups compared with the VD replete rats (only borderline significant). In accordance, other animal studies conducted on jaguars, boars, and mice showed positive (borderline significant) effects of VD supplements on quality variables such as sperm morphology and sperm motility (Audet et al. 2004, Da Paz 2006, Hirai et al. 2009).

Only two studies have investigated associations between serum $25-\mathrm{OHD}_{3}$ and semen quality/reproductive hormones in humans (Blomberg Jensen et al. 2011, Ramlau-Hansen et al. 2011). Ramlau-Hansen et al. (2011) presented positive correlations between serum $25-\mathrm{OHD}_{3}$ and sperm motility in healthy young men (Ramlau-Hansen et al. 2011), but the association was not significant after adjustment for several confounders without reporting indication or influence. They found no association with sperm counts, morphology, or inhibin B level despite an unadjusted positive correlation with FSH. The conclusions obtained from this study are limited by some methodological problems, but especially the low frequency of men with VD deficiency and a remarkable high median serum $25-\mathrm{OHD}_{3}$ compared with other Danish studies makes it difficult to establish whether VD deficiency is associated with impaired semen variables (Mosekilde et al. 2005, Frost et al. 2010, Blomberg Jensen et al. 2011, Thuesen et al. 2011). They stratified their cohort into tertiles, which resulted in a comparison between various degrees of VD sufficiency. An extensive analysis conducted in a comparable cohort size of Danish men found the same positive association between serum $25-\mathrm{OHD}_{3}$ and sperm motility in addition to a positive association with the percentage of sperm with normal morphology and progressive sperm motility. Interestingly, the association was even stronger with progressive sperm motility, and the positive associations with total and progressive sperm motility persisted after adjustment of relevant confounders such as season, time from ejaculation to motility assessment, and serum calcium. The positive association between serum $25-\mathrm{OHD}_{3}$ and sperm motility was corroborated in a small mixed cohort of normal and infertile men (Blomberg Jensen et al. 2012). These observations indicate that VD deficiency in humans results in the same phenotype as reported in both VD-deficient animals and $V d r$ KO mice presenting with a low fraction of motile spermatozoa (Bouillon et al. 2008). This may be mediated directly by VD as $1,25(\mathrm{OH})_{2} \mathrm{D}_{3}$ induced sperm motility in human spermatozoa in vitro and the associations between serum VD levels and sperm motility were not influenced by adjustment for serum calcium or albumin-corrected calcium levels. However, cross-sectional studies are warranted to determine whether the associations persist in infertile men, and RCTs are required to determine the clinical potential of cholecalciferol supplements to infertile men.

\section{Regulation of testicular VD metabolism and putative downstream mediators}

Testicular VD metabolism seems to be regulated differently compared with the tight systemic regulation of VD (Lips 2006, Fleet 2008). An animal study comparing VD-deficient ( $-\mathrm{VD})$ and control-treated rats raised on a normal VD-sufficient (+VD) diet showed threefold elevated $V d r$ levels in kidney but not in testis or in other extra-renal tissues. Upregulation of $V d r$ also occurred in kidney of $+\mathrm{VD}$ rats 1 day after a single $100 \mathrm{ng}$ dose of $1,25(\mathrm{OH})_{2} \mathrm{D}_{3}$, but no changes were seen in intestine, testis, or lung. Following infusion of $1,25(\mathrm{OH})_{2} \mathrm{D}_{3}$ into $-\mathrm{VD}$ rats that were kept normocalcemic, the renal $V d r$ was upregulated, but testicular $V d r$ levels were again unaffected (Gensure et al. 1998). This shows that $V d r$ expression is regulated differently in the kidney and testis. This may be important, because ICC studies using human semen samples reported that a higher fraction of spermatozoa from fertile men express VDR than sperm from infertile men (Aquila et al. 2008, 2009, Blomberg Jensen et al. 2012). Likewise, $1,25(\mathrm{OH})_{2} \mathrm{D}_{3}$ is a known inducer of testicular aromatase expression, and both aromatase level and activity are lower in the immotile rather than the motile fraction of sperm from the same semen sample. In addition, a lower abundance of aromatase mRNA was found in spermatozoa from asthenospermic (low motility), teratospermic (abnormal morphology), and asthenoteratospermic men compared with controls (Carreau et al. 2009), which is comparable to the reported expression pattern for VDR and the VD metabolizing enzymes (Blomberg Jensen et al. 2012). However, as indicated by $V d r \mathrm{KO}$ mice, it is plausible that the main site for the VD-mediated reproductive effects is the male reproductive tract (epididymis) rather than the testis. Estrogen regulates fluid reabsorption in the reproductive tract and the estrogen receptor $(E r) \propto \mathrm{KO}$ male is infertile, although testes histology appears normal until puberty, when the tubules begin to degenerate. Sperm recovered from the cauda epididymis of these mice exhibit reduced motility and failed to fertilize eggs in vitro (Hess et al. 1997, Carreau \& Hess 2010, Joseph et al. 2010). Moreover, male mice with deficient aromatase do not present with a severe phenotype and were initially fertile but developed progressive infertility and disrupted spermatogenesis after 4.5 months to 1 year. They presented with spermatogenic arrest and Leydig cell hyperplasia/hypertrophy despite no increase in gonadotropins or androgens (Robertson et al. 1999). Moreover, Trpv6 KO mice 
have severely impaired fertility due to a very low fraction of motile spermatozoa. TRPV6 (VD-regulated gene) is expressed in the epididymis, but not in the testis and supports that the site of the VD-mediated effects on male reproduction is in the epididymis (Weissgerber et al. 2011). Immature Sertoli cells express VDR, aromatase, and $\mathrm{AMH}$, while mature Sertoli cells do not express any of these proteins. The proposed actions of VD on immature Sertoli cells have recently been reviewed and will not be discussed further here, but it is likely that VD may be a regulator of AMH and GGT in immature Sertoli cells (Zanatta et al. 2011c). The findings described earlier indicate that most of the VD-mediated effects in the testis and male reproductive tract are mediated through estrogen synthesis or aberrant expression of ER. However, VD regulates transcription of more than 1000 genes though binding to the genomic pocket of the VDR (Haussler et al. 2011). The nuclear VDR expression in human spermatogonia indicates that VD exerts genomic actions there (Nangia et al. 2007, Blomberg Jensen et al. 2010b). Few have addressed the nuclear effects in male reproduction, but some of the known VD-regulated genes besides CYP19A1 could also be of importance for male reproductive function: calcium transport and homeostasis (NCX, PMCA,
TRPV5-6, Calbindin 9k, 28k, PTHrP, Calretinin, and CaSR), endocrine (IGFBP3, MIS(AMH), CYP19A1, and VEGF), and cell cycle control (p21, p63, FOXO1, and RUNX2) (Haussler et al. 2011).

The expression of $V D R$ in human spermatozoa indicates that $1,25(\mathrm{OH})_{2} \mathrm{D}_{3}$ mediates a direct effect in mature spermatozoa. Human spermatozoa are virtually transcriptionally silent, but activation of the alternative ligand binding pocket of VDR mediates several nongenomic effects, which may be of importance for sperm function as recently reviewed (Blomberg Jensen \& Dissing 2012). Briefly, $1 \mathrm{nM} 1,25(\mathrm{OH})_{2} \mathrm{D}_{3}$ induce a rapid increase in intracellular calcium concentration $\left[\mathrm{Ca}^{2+}\right]_{i}$ in human spermatozoa in vitro (Fig. 5). The increase in $\left[\mathrm{Ca}^{2+}\right]_{i}$ was abrogated by the nongenomic VDR antagonist $1 \beta, 25(\mathrm{OH}){ }_{2} \mathrm{D}_{3}$, while the specific agonist for VDR-ap (JN) increased $\left[\mathrm{Ca}^{2+}\right]_{i}$ with similar kinetics as $1,25(\mathrm{OH})_{2} \mathrm{D}_{3}$, thereby confirming that this ionotropic effect was mediated by VDR activation (Blomberg Jensen et al. 2011, 2012). The rise in $\left[\mathrm{Ca}^{2+}\right]_{\mathrm{i}}$ originated from $\mathrm{Ca}^{2+}$-release from intracellular stores as inhibition of phospholipase $\mathrm{C}$ diminished the $1,25(\mathrm{OH})_{2} \mathrm{D}_{3}$-mediated $\mathrm{Ca}^{2+}$ response, while suspending spermatozoa in a nominally $\mathrm{Ca}^{2+}$-free medium did not abrogate the VD-mediated $\mathrm{Ca}^{2+}$ rise (Blomberg
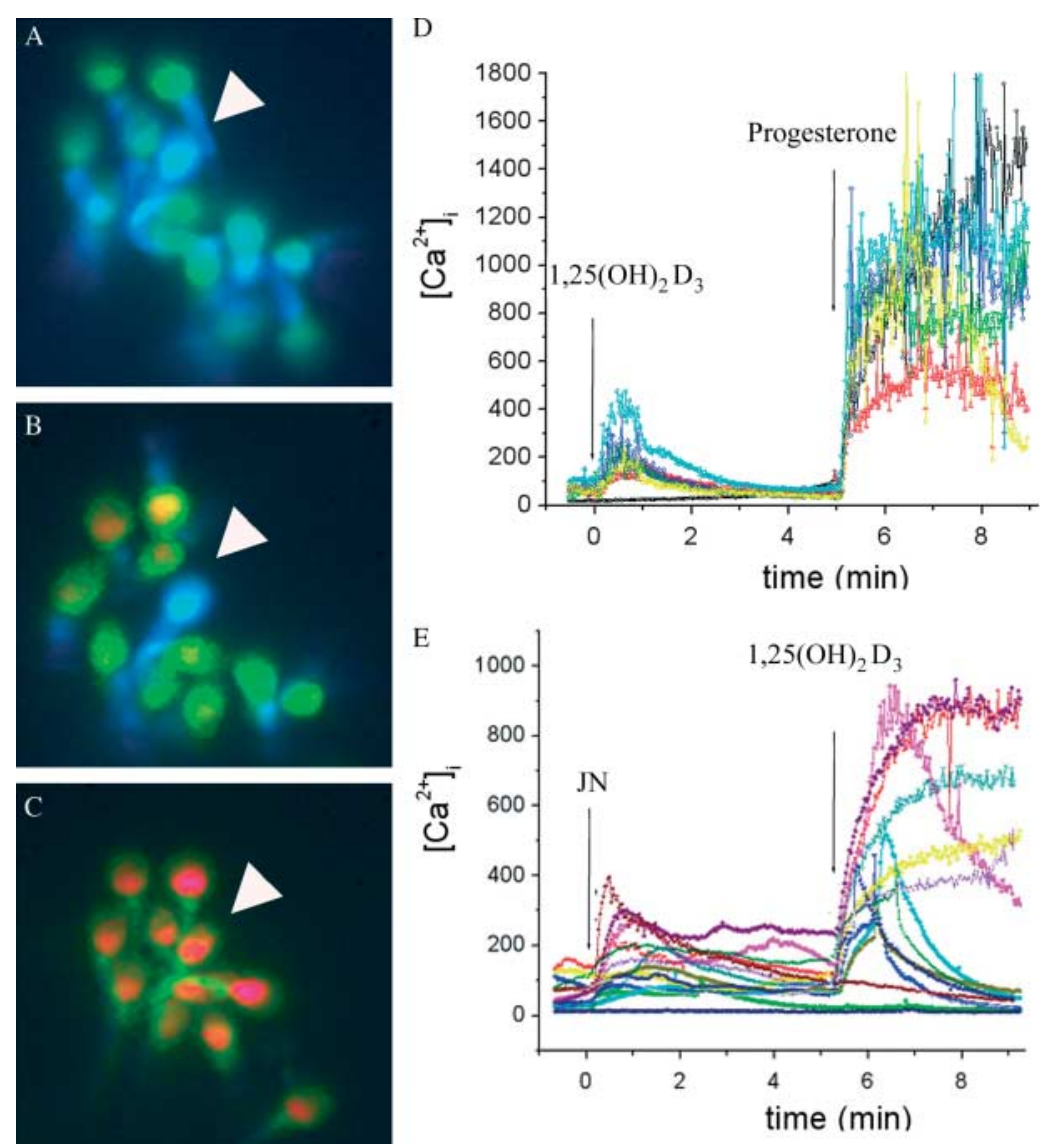

www.reproduction-online.org
Figure 5 Vitamin $\mathrm{D}$ (VD) and intracellular calcium concentration $\left[\mathrm{Ca}^{2+}\right]_{i}$ in human spermatozoa. (A) Fura-2-loaded spermatozoa. Color indicates intracellular calcium concentration (low to high: blue, green, yellow, and red). (B) Rapid change in intracellular calcium levels after addition of $1 \mathrm{nM}$ $1,25(\mathrm{OH})_{2} \mathrm{D}_{3}$, arrowhead indicates one unresponsive spermatozoa. (C) Corresponding changes in $\left[\mathrm{Ca}^{2+}\right]_{i}$ after addition of $10 \mu \mathrm{M}$ progesterone, arrowhead indicates the spermatozoa being unresponsive to $1 \mathrm{nM}$ $1,25(\mathrm{OH})_{2} \mathrm{D}_{3}$. (D) Increase in $\left[\mathrm{Ca}^{2+}\right]_{\mathrm{i}}$ following treatment with $1 \mathrm{nM} 1,25(\mathrm{OH})_{2} \mathrm{D}_{3}$ and $10 \mu \mathrm{M}$ progesterone, each trace represents calcium levels in a single spermatozoa and arrows indicate the spermatozoa being unresponsive to $1,25(\mathrm{OH})_{2} \mathrm{D}_{3}$ (black trace). (E) Increase in $\left[\mathrm{Ca}^{2+}\right]_{i}$ following treatment with $1 \mathrm{nM}$

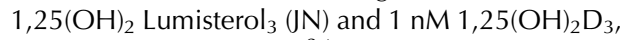
each trace represents $\left[\mathrm{Ca}^{2+}\right]_{i}$ in single spermatozoa. Note different gradations. Figure reproduced from Blomberg Jensen $M$, Jørgensen A, Nielsen JE, Leffers H, Andersen AN, Skakkebaek NE, Juul A, Rajpert-De-Meyts E \& Jørgensen N 2012 Expression of the vitamin D metabolizing enzyme CYP24A1 at the annulus of human spermatozoa may serve as a novel marker of semen quality. International Journal of Andrology. By permission of John Wiley and Sons. 
Jensen et al. 2011). The spatiotemporal kinetics of the VD response differed from the progesterone-mediated increase in $\left[\mathrm{Ca}^{2+}\right]_{i}$ as the VD-mediated $\mathrm{Ca}^{2+}$ rise was not observed in the tail region and was independent of extracellular $\mathrm{Ca}^{2+}$ and therefore not mediated by CatSper (Blomberg Jensen et al. 2012). Moreover, pretreatment with $1,25(\mathrm{OH})_{2} \mathrm{D}_{3}$ and the use of VDR antagonist did not abrogate the progesterone response, which supports different mechanisms of action (Blomberg Jensen et al. 2011). A functional role of the VD-mediated $\mathrm{Ca}^{2+}$ increase was supported by the $1,25(\mathrm{OH})_{2} \mathrm{D}_{3}$-mediated increase in sperm motility and induction of the acrosome reaction in vitro (Blomberg Jensen et al. 2011). However, the functional importance of these findings depends on the concentration of VD progenitors in the seminal fluid and in the vicinity of the cumulus-oophorous complex in the female reproductive tract.

\section{Perspectives}

From animal and human studies, it is evident that VD is important for optimal male reproductive function. Some of the VD effects are presumably mediated locally by the presence of VDR and the VD metabolizing enzymes in adult male germ cells, Leydig cells, and male reproductive tract, while other actions may be influenced by the systemic effects of VD serum levels. The low expression of $V D R$ and VD metabolizing enzymes in spermatozoa from infertile men compared with normal men supports a role for the local VD metabolism and may have functional consequences. Especially, as $1,25(\mathrm{OH})_{2} \mathrm{D}_{3}$ mediates a nongenomic increase in intracellular calcium concentration, which seems to be important for sperm function especially following capacitation in the female reproductive tract. Most of the VD effects in the testes appear to be mediated through estrogen biosynthesis, but other candidate genes involved in calcium homeostasis, endocrine function, and cell cycle control may be involved. An association between serum $25-\mathrm{OHD}_{3}$ and testosterone production remains to be proven, although it is plausible that the declining serum VD levels with age may be involved in the age-related loss of function of both gonads and bone, but further studies are needed to determine causality. Moreover, both local VD metabolism and serum levels of $25-\mathrm{OHD}_{3}$ may have a direct effect on sperm motility in both animal and humans even after considering the indirect effect mediated by calcium homeostasis. The effects on sperm motility may be mediated mainly in epididymis rather than the testes, but further studies are needed to determine the exact site and mechanisms of action and to investigate whether supplementation of cholecalciferol improves semen quality in VD-deficient men.

\section{Declaration of interest}

The author declares that there is no conflict of interest that could be perceived as prejudicing the impartiality of the review.

\section{Funding}

Rigshospitalet, Novo-Nordisk Foundation, Aase and Ejnar Danielsens Foundation, and Danish Agency for Science, Technology and Innovation.

\section{Acknowledgements}

The author wishes to thank all his colleagues at the department of Growth and Reproduction for their contribution and efforts in elucidating some of the effects of VD on male reproduction. Especially, John Erik Nielsen, Anne Jørgensen, Niels Jørgensen, Niels E Skakkebaek, Anders Juul, Anna-Maria Andersson, and Ewa Rajpert-De Meyts for fruitful discussions and valuable guidance assistance for several years. The author specially thank John, Anne, and Ewa for their constructive comments and proofreading of this manuscript.

\section{References}

van Abel M, Hoenderop JG, Dardenne $\mathrm{O}$, St Arnaud R, van Os $\mathbf{C H}$, Van Leeuwen HJ \& Bindels RJ 2002 1,25-Dihydroxyvitamin D(3)independent stimulatory effect of estrogen on the expression of $\mathrm{ECaC} 1$ in the kidney. Journal of the American Society of Nephrology 13 2102-2109. (doi:10.1097/01.ASN.0000022423.34922.2A)

van Abel M, Huybers S, Hoenderop JG, van der Kemp AW, van Leeuwen JP \& Bindels RJ 2006 Age-dependent alterations in $\mathrm{Ca}^{2+}$ homeostasis: role of TRPV5 and TRPV6. American Journal of Physiology. Renal Physiology 291 F1177-F1183. (doi:10.1152/ajprenal.00038.2006)

Akeno N, Saikatsu S, Kawane T \& Horiuchi N 1997 Mouse vitamin D-24-hydroxylase: molecular cloning, tissue distribution, and transcriptional regulation by $1 \alpha, 25$-dihydroxyvitamin $\mathrm{D}_{3}$. Endocrinology 138 2233-2240. (doi:10.1210/en.138.6.2233)

Akerstrom VL \& Walters MR 1992 Physiological effects of 1,25-dihydroxyvitamin $\mathrm{D}_{3}$ in TM4 Sertoli cell line. American Journal of Physiology $\mathbf{2 6 2}$ E884-E890.

Aquila S, Guido C, Perrotta I, Tripepi S, Nastro A \& Ando S 2008 Human sperm anatomy: ultrastructural localization of $1 \alpha, 25$-dihydroxyvitamin D receptor and its possible role in the human male gamete. Journal of Anatomy 213 555-564. (doi:10.1111/j.1469-7580.2008.00975.x)

Aquila S, Guido C, Middea E, Perrotta I, Bruno R, Pellegrino M \& Ando S 2009 Human male gamete endocrinology: $1 \alpha, 25$-dihydroxyvitamin $D_{3}$ $\left(1,25(\mathrm{OH})_{2} \mathrm{D}_{3}\right)$ regulates different aspects of human sperm biology and metabolism. Reproductive Biology and Endocrinology 7140. (doi:10.1186/1477-7827-7-140)

Audet I, Laforest JP, Martineau GP \& Matte J 2004 Effect of vitamin supplements on some aspects of performance, vitamin status, and semen quality in boars. Journal of Animal Science 82 626-633.

Bieche I, Narjoz C, Asselah T, Vacher S, Marcellin P, Lidereau R, Beaune P \& de Waziers I 2007 Reverse transcriptase-PCR quantification of mRNA levels from cytochrome (CYP)1, CYP2 and CYP3 families in 22 different human tissues. Pharmacogenetics and Genomics 17 731-742. (doi:10.1097/FPC.0b013e32810f2e58)

Bischoff-Ferrari HA 2008 Optimal serum 25-hydroxyvitamin D levels for multiple health outcomes. Advances in Experimental Medicine and Biology 624 55-71.

Blomberg Jensen M \& Dissing S 2012 Non genomic effects of vitamin D in human spermatozoa. Steroids [in press]. (doi:10.1016/j.steroids.2012. 02.020) 
Blomberg Jensen M, Andersen CB, Nielsen JE, Bagi P, Jorgensen A, Juul A \& Leffers H 2010a Expression of the vitamin D receptor, 25-hydroxylases, $1 \alpha$-hydroxylase and 24-hydroxylase in the human kidney and renal clear cell cancer. Journal of Steroid Biochemistry and Molecular Biology 121 376-382. (doi:10.1016/j.jsbmb.2010.03.069)

Blomberg Jensen $M$, Nielsen JE, Jorgensen A, Rajpert-de ME, Kristensen DM, Jorgensen N, Skakkebaek NE, Juul A \& Leffers $H$ $2010 b$ Vitamin D receptor and vitamin D metabolizing enzymes are expressed in the human male reproductive tract. Human Reproduction 25 1303-1311. (doi:10.1093/humrep/deq024)

Blomberg Jensen $M$, Bjerrum PJ, Jessen TE, Nielsen JE, Joensen UN, Olesen IA, Petersen JH, Juul A, Dissing S \& Jorgensen N 2011 Vitamin D is positively associated with sperm motility and increases intracellular calcium in human spermatozoa. Human Reproduction 26 1307-1317. (doi:10.1093/humrep/der059)

Blomberg Jensen $M$, Jørgensen A, Nielsen JE, Leffers $H$, Andersen AN, Skakkebaek NE, Juul A, Rajpert-De-Meyts E \& Jørgensen N 2012 Expression of the vitamin D metabolizing enzyme CYP24A1 at the annulus of human spermatozoa may serve as a novel marker of semen quality. International Journal of Andrology [in press]. (doi:10.1111/j. 1365-2605.2012.01256)

Blumberg A, Wildbolz A, Descoeudres C, Hennes U, Dambacher MA, Fischer JA \& Weidmann P 1980 Influence of 1,25 dihydroxycholecalciferol on sexual dysfunction and related endocrine parameters in patients on maintenance hemodialysis. Clinical Nephrology 13 208-214.

Bonde JP, Ernst E, Jensen TK, Hjollund NH, Kolstad $H$, Henriksen TB, Scheike T, Giwercman A, Olsen J \& Skakkebaek NE 1998 Relation between semen quality and fertility: a population-based study of 430 first-pregnancy planners. Lancet 352 1172-1177. (doi:10.1016/S01406736(97)10514-1)

Bouillon R, Carmeliet G, Verlinden L, van Etten E, Verstuyf A, Luderer HF, Lieben L, Mathieu C \& Demay M 2008 Vitamin D and human health: lessons from vitamin D receptor null mice. Endocrine Reviews 29 726-776. (doi:10.1210/er.2008-0004)

Braga V, Sangalli A, Malerba G, Mottes M, Mirandola S, Gatti D, Rossini M, Zamboni M \& Adami S 2002 Relationship among VDR (Bsml and Fokl), COLIA1, and CTR polymorphisms with bone mass, bone turnover markers, and sex hormones in men. Calcified Tissue International 70 457-462. (doi:10.1007/s00223-001-1088-9)

Bremmer F, Thelen P, Pottek T, Behnes CL, Radzun HJ \& Schweyer S 2012 Expression and function of the vitamin d receptor in malignant germ cell tumour of the testis. Anticancer Research 32 341-349.

Carreau S \& Hess RA 2010 Oestrogens and spermatogenesis. Philosophical Transactions of the Royal Society of London. Series B: Biological Sciences 365 1517-1535. (doi:10.1098/rstb.2009.0235)

Carreau S, Delalande C \& Galeraud-Denis I 2009 Mammalian sperm quality and aromatase expression. Microscopic Research and Technique 72 552-557. (doi:10.1002/jemt.20703)

Ceglia L, Chiu GR, Harris SS \& Araujo AB 2011 Serum 25-hydroxyvitamin $\mathrm{D}$ concentration and physical function in adult men. Clinical Endocrinology 74 370-376. (doi:10.1111/j.1365-2265.2010.03926.x)

Chen RY, Nordin BE, Need AG, Scopacasa F, Wishart J, Morris HA \& Horowitz M 2008 Relationship between calcium absorption and plasma dehydroepiandrosterone sulphate (DHEAS) in healthy males. Clinical Endocrinology 69 864-869. (doi:10.1111/j.1365-2265.2008. 03272.x)

Cheng JB, Motola DL, Mangelsdorf DJ \& Russell DW 2003 De-orphanization of cytochrome P450 2R1: a microsomal vitamin D 25-hydroxilase. Journal of Biological Chemistry 278 38084-38093. (doi:10.1074/jbc.M307028200)

Choudhary D, Jansson I, Schenkman JB, Sarfarazi M \& Stoilov I 2003 Comparative expression profiling of 40 mouse cytochrome $\mathbf{P} 450$ genes in embryonic and adult tissues. Archives of Biochemistry and Biophysics 414 91-100. (doi:10.1016/S0003-9861(03)00174-7)

Choudhary D, Jansson I, Stoilov I, Sarfarazi M \& Schenkman JB 2005 Expression patterns of mouse and human CYP orthologs (families 1-4) during development and in different adult tissues. Archives of Biochemistry and Biophysics 436 50-61. (doi:10.1016/j.abb.2005.02.001)

Corbett ST, Hill O \& Nangia AK 2006 Vitamin D receptor found in human sperm. Urology 68 1345-1349. (doi:10.1016/j.urology.2006.09.011)

Da Paz RCR, Morato Gonçalves R, Carciofi AC, Guimarães MABV, Pessuti C, Ferraz Santos E, Ferreira F \& Barnabe RC 2006 Influence of nutrition on the quality of semen in Jaguars in Brazilian zoos. International Zoology Yearbook 40 351-359. (doi:10.1111/j.17481090.2006.00351.x)

Dauber A, Nguyen TT, Sochett E, Cole DE, Horst R, Abrams SA, Carpenter TO \& Hirschhorn JN 2011 Genetic defect in CYP24A1, the vitamin D 24-hydroxylase gene, in a patient with severe infantile hypercalcemia. Journal of Clinical Endocrinology and Metabolism 23 1972-1978.

Dawson-Hughes B, Heaney RP, Holick MF, Lips P, Meunier PJ \& Vieth R 2005 Estimates of optimal vitamin D status. Osteoporosis International 16 713-716. (doi:10.1007/s00198-005-1867-7)

Dent CE \& Harris H 1956 Hereditary forms of rickets and osteomalacia. Journal of Bone \& Joint Surgery, British Volume 38-B 204-226.

Echchgadda I, Song CS, Roy AK \& Chatterjee B 2004 Dehydroepiandrosterone sulfotransferase is a target for transcriptional induction by the vitamin D receptor. Molecular Pharmacology 65 720-729. (doi:10.1124/ mol.65.3.720)

Fleet JC 2008 Molecular actions of vitamin D contributing to cancer prevention. Molecular Aspects of Medicine 29 388-396. (doi:10.1016/j. mam.2008.07.003)

Fleet JC \& Schoch RD 2010 Molecular mechanisms for regulation of intestinal calcium absorption by vitamin D and other factors. Critical Reviews in Clinical Laboratory Sciences 47 181-195. (doi:10.3109/ 10408363.2010.536429)

Foresta C, Selice R, Di MA \& Strapazzon G 2010 Testiculopathy and vitamin D insufficiency. Lancet 376 1301. (doi:10.1016/S01406736(10)61916-2)

Foresta C, Strapazzon G, De TL, Perilli L, Di MA, Muciaccia B, Sartori L \& Selice R 2011 Bone mineral density and testicular failure: evidence for a role of vitamin D 25-hydroxylase in human testis. Journal of Clinical Endocrinology and Metabolism 96 E646-E652. (doi:10.1210/ jc.2010-1628)

Frost M, Abrahamsen B, Nielsen T, Hagen C, Andersen M \& Brixen K 2010 Vitamin D status and PTH in young men: a cross-sectional study on associations with bone mineral density, body composition and glucose metabolism. Clinical Endocrinology 73 573-580. (doi:10.1111/j.13652265.2010.03847.x)

Fukumoto S \& Martin TJ 2009 Bone as an endocrine organ. Trends in Endocrinology and Metabolism 20 230-236. (doi:10.1016/j.tem.2009. 02.001)

Gensure RC, Riggle PC, Antrobus SD \& Walters MR 1991 Evidence for two classes of 1,25-dihydroxyvitamin $\mathrm{D}_{3}$ binding sites in classical vs. nonclassical target tissues. Biochemical and Biophysical Research Communications 180 867-873. (doi:10.1016/S0006-291X(05)81145-3)

Gensure RC, Antrobus SD, Fox J, Okwueze M, Talton SY \& Walters MR 1998 Homologous up-regulation of vitamin D receptors is tissue specific in the rat. Journal of Bone and Mineral Research 13 454-463. (doi:10.1359/jbmr.1998.13.3.454)

Giovannucci E, Liu Y, Rimm EB, Hollis BW, Fuchs CS, Stampfer MJ \& Willett WC 2006 Prospective study of predictors of vitamin D status and cancer incidence and mortality in men. Journal of the National Cancer Institute 98 451-459. (doi:10.1093/jnci/djj101)

Gray RW, Omdahl JL, Ghazarian JG \& DeLuca HF 1972 25-Hydroxycholecalciferol-1-hydroxylase. Subcellular location and properties. Journal of Biological Chemistry 247 7528-7532.

Habib FK, Maddy SQ \& Gelly KJ 1990 Characterisation of receptors for 1,25-dihydroxyvitamin $D_{3}$ in the human testis. Journal of Steroid Biochemistry 35 195-199. (doi:10.1016/0022-4731(90)90274-V)

Hagenfeldt Y, Linde K, Sjoberg HE, Zumkeller W \& Arver S 1992 Testosterone increases serum 1,25-dihydroxyvitamin D and insulin-like growth factor-I in hypogonadal men. International Journal of Andrology 15 93-102. (doi:10.1111/j.1365-2605.1992.tb01118.x)

Haussler MR, Jurutka PW, Mizwicki M \& Norman AW 2011 Vitamin D receptor (VDR)-mediated actions of $1 \alpha, 25(\mathrm{OH})(2)$ vitamin $\mathrm{D}$ (3): genomic and non-genomic mechanisms. Best Practice \& Research. Clinical Endocrinology \& Metabolism 25 543-559. (doi:10.1016/j.beem.2011. 05.010)

Hawa NS, Cockerill FJ, Vadher S, Hewison M, Rut AR, Pike JW, O'Riordan JL \& Farrow SM 1996 Identification of a novel mutation in hereditary vitamin D resistant rickets causing exon skipping. Clinical Endocrinology 45 85-92. (doi:10.1111/j.1365-2265.1996.tb02064.x) 
Heaney RP \& Holick MF 2011 Why the IOM recommendations for vitamin D are deficient. Journal of Bone and Mineral Research 26 455-457. (doi:10.1002/jbmr.328)

Hess RA, Bunick D, Lee KH, Bahr J, Taylor JA, Korach KS \& Lubahn DB 1997 A role for oestrogens in the male reproductive system. Nature $\mathbf{3 9 0}$ 509-512. (doi:10.1038/37352)

Hirai T, Tsujimura A, Ueda T, Fujita K, Matsuoka Y, Takao T, Miyagawa Y, Koike N \& Okuyama A 2009 Effect of 1,25-dihydroxyvitamin d on testicular morphology and gene expression in experimental cryptorchid mouse: testis specific cDNA microarray analysis and potential implication in male infertility. Journal of Urology 181 1487-1492. (doi:10.1016/j.juro.2008.11.007)

Hochberg Z, Borochowitz Z, Benderli A, Vardi P, Oren S, Spirer Z, Heyman I \& Weisman Y 1985 Does 1,25-dihydroxyvitamin D participate in the regulation of hormone release from endocrine glands? Journal of Clinical Endocrinology and Metabolism 60 57-61. (doi:10. 1210/jcem-60-1-57)

Holick MF 2006 High prevalence of vitamin D inadequacy and implications for health. Mayo Clinic Proceedings 81 353-373. (doi:10.4065/81. 3.353)

Holick MF \& Chen TC 2008 Vitamin D deficiency: a worldwide problem with health consequences. American Journal of Clinical Nutrition $\mathbf{8 7}$ 1080S-1086S.

Holick MF, Binkley NC, Bischoff-Ferrari HA, Gordon CM, Hanley DA, Heaney RP, Murad MH \& Weaver CM 2011 Evaluation, treatment, and prevention of vitamin D deficiency: an Endocrine Society clinical practice guideline. Journal of Clinical Endocrinology and Metabolism 96 1911-1930. (doi:10.1210/jc.2011-0385)

Hsu YJ, Dimke H, Schoeber JP, Hsu SC, Lin SH, Chu P, Hoenderop JG \& Bindels RJ 2010 Testosterone increases urinary calcium excretion and inhibits expression of renal calcium transport proteins. Kidney International 77 601-608. (doi:10.1038/ki.2009.522)

Hwang YC, Jeong IK, Ahn KJ \& Chung HY 2011 Circulating osteocalcin level is associated with improved glucose tolerance, insulin secretion and sensitivity independent of the plasma adiponectin level. Osteoporosis International 23 1337-1342. (doi:10.1007/s00198-011-1679-x)

Hyldstrup L, Christiansen C, Nielsen MD \& Transbol I 1984 Testosterone treatment and arginine-induced growth hormone stimulation in male delayed puberty: effects on serum calcium, phosphate and vitamin D metabolites. Scandinavian Journal of Clinical and Laboratory Investigation 44 335-339. (doi:10.3109/00365518409083816)

Ikawa M, Inoue N, Benham AM \& Okabe M 2010 Fertilization: a sperm's journey to and interaction with the oocyte. Journal of Clinical Investigation 120 984-994. (doi:10.1172/JCl41585)

Inpanbutr N, Reiswig JD, Bacon WL, Slemons RD \& Iacopino AM 1996 Effect of vitamin D on testicular CaBP28K expression and serum testosterone in chickens. Biology of Reproduction 54 242-248. (doi:10.1095/biolreprod54.1.242)

Jackson JA, Kleerekoper M, Parfitt AM, Rao DS, Villanueva AR \& Frame B 1987 Bone histomorphometry in hypogonadal and eugonadal men with spinal osteoporosis. Journal of Clinical Endocrinology and Metabolism 65 53-58. (doi:10.1210/jcem-65-1-53)

Ji HF \& Shen L 2011 CYP24A1 mutations in idiopathic infantile hypercalcemia. New England Journal of Medicine 365 1741-1743. (doi:10.1056/NEJMc1110226)

Jimenez-Gonzalez C, Michelangeli F, Harper CV, Barratt CL \& Publicover SJ 2006 Calcium signalling in human spermatozoa: a specialized 'toolkit' of channels, transporters and stores. Human Reproduction Update 12 253-267. (doi:10.1093/humupd/dmi050)

Johnson LE \& DeLuca HF 2001 Vitamin D receptor null mutant mice fed high levels of calcium are fertile. Journal of Nutrition 131 1787-1791.

Johnson JA, Grande JP, Roche PC \& Kumar R 1996 Immunohistochemical detection and distribution of the 1,25-dihydroxyvitamin $\mathrm{D}_{3}$ receptor in rat reproductive tissues. Histochemistry and Cell Biology 105 7-15. (doi:10.1007/BF01450873)

Jones G, Prosser DE \& Kaufmann M 2011 Hydroxyvitamin D-24-hydroxylase (CYP24A1): its important role in the degradation of vitamin D. Archives of Biochemistry and Biophysics 523 9-18. (doi:10.1016/j.abb. 2011.11.003)

Joseph A, Hess RA, Schaeffer DJ, Ko C, Hudgin-Spivey S, Chambon P \& Shur BD 2010 Absence of estrogen receptor $\alpha$ leads to physiological alterations in the mouse epididymis and consequent defects in sperm function. Biology of Reproduction 82 948-957. (doi:10.1095/biolreprod. 109.079889)

Kagi U, Chafouleas JG, Norman AW \& Heizmann CW 1988 Developmental appearance of the $\mathrm{Ca}^{2+}$-binding proteins parvalbumin, calbindin D-28K, S-100 proteins and calmodulin during testicular development in the rat. Cell and Tissue Research 252 359-365. (doi:10.1007/ BF00214378)

Kaplan SA, Meehan AG \& Shah A 2006 The age related decrease in testosterone is significantly exacerbated in obese men with the metabolic syndrome. What are the implications for the relatively high incidence of erectile dysfunction observed in these men? Journal of Urology $\mathbf{1 7 6}$ 1524-1527. (doi:10.1016/j.juro.2006.06.003)

Kastelan D, Korsic M, Kraljevic I, Dusek T, Giljevic Z \& Korsic M 2009 Low serum 25-hydroxyvitamin D concentrations in healthy young males. Journal of Endocrinological Investigation 32 562-563.

Kidroni G, Har-Nir R, Menezel J, Frutkoff IW, Palti Z \& Ron M 1983 Vitamin $\mathrm{D}_{3}$ metabolites in rat epididymis: high 24,25-dihydroxy vitamin $\mathrm{D}_{3}$ levels in the cauda region. Biochemical and Biophysical Research Communications 113 982-989. (doi:10.1016/0006-291X(83)91095-1)

Kinuta K, Tanaka H, Moriwake T, Aya K, Kato S \& Seino Y 2000 Vitamin D is an important factor in estrogen biosynthesis of both female and male gonads. Endocrinology 141 1317-1324. (doi:10.1210/en.141.4.1317)

Kovacs CS, Woodland ML, Fudge NJ \& Friel JK 2005 The vitamin D receptor is not required for fetal mineral homeostasis or for the regulation of placental calcium transfer in mice. American Journal of Physiology. Endocrinology and Metabolism 289 E133-E144. (doi:10.1152/ajpendo. 00354.2004)

Krabbe S, Hummer L \& Christiansen C 1986 Serum levels of vitamin D metabolites and testosterone in male puberty. Journal of Clinical Endocrinology and Metabolism 62 503-507. (doi:10.1210/jcem-62-3-503)

Kream BE, Yamada S, Schnoes HK \& DeLuca HF 1977 Specific cytosolbinding protein for 1,25-dihydroxyvitamin $\mathrm{D}_{3}$ in rat intestine. Journal of Biological Chemistry 252 4501-4505.

Krishnan AV, Swami S \& Feldman D 2010a Vitamin D and breast cancer: inhibition of estrogen synthesis and signaling. Journal of Steroid Biochemistry and Molecular Biology 121 343-348. (doi:10.1016/j. jsbmb.2010.02.009)

Krishnan AV, Swami S, Peng L, Wang J, Moreno J \& Feldman D $2010 b$ Tissue-selective regulation of aromatase expression by calcitriol: implications for breast cancer therapy. Endocrinology 151 32-42. (doi:10.1210/en.2009-0855)

Kwiecinski GG, Petrie GI \& DeLuca HF 1989 Vitamin D is necessary for reproductive functions of the male rat. Journal of Nutrition 119 741-744.

Lee DM, Tajar A, Pye SR, Boonen S, Vanderschueren D, Bouillon R, O'Neill TW, Bartfai G, Casanueva FF, Finn JD et al. 2012 Association of hypogonadism with vitamin D status: the European Male Ageing Study. European Journal of Endocrinology 166 77-85. (doi:10.1530/EJE11-0743)

Levy FO, Eikvar L, Jutte NH, Cervenka J, Yoganathan T \& Hansson V 1985a Appearance of the rat testicular receptor for calcitriol (1,25-dihydroxyvitamin $\mathrm{D}_{3}$ ) during development. Journal of Steroid Biochemistry 23 51-56. (doi:10.1016/0022-4731(85)90259-6)

Levy FO, Eikvar L, Jutte NH, Froysa A, Tvermyr SM \& Hansson V 1985b Properties and compartmentalization of the testicular receptor for 1,25-dihydroxyvitamin $\mathrm{D}_{3}$. Journal of Steroid Biochemistry 22 453-460. (doi:10.1016/0022-4731(85)90162-1)

Li SL, Wang XH, Wang HP, Yang ZH, Gao WC \& Pu XY 2008 Expression of TRPM and TRPV channel family mRNA in rat spermatogenic cells. Nan Fang Yi Ke Da Xue Xue Bao 28 2150-2153.

Lips P 2006 Vitamin D physiology. Progress in Biophysics and Molecular Biology 92 4-8. (doi:10.1016/j.pbiomolbio.2006.02.016)

Lips P, Bouillon R, van Schoor NM, Vanderschueren D, Verschueren S, Kuchuk N, Milisen K \& Boonen S 2010 Reducing fracture risk with calcium and vitamin D. Clinical Endocrinology 73 277-285.

Livshits G, Karasik D \& Seibel MJ 1999 Statistical genetic analysis of plasma levels of vitamin D: familial study. Annals of Human Genetics 63 429-439. (doi:10.1046/j.1469-1809.1999.6350429.x)

Lundqvist J, Norlin M \& Wikvall K 2011 1 $\alpha, 25$-Dihydroxyvitamin $D_{3}$ exerts tissue-specific effects on estrogen and androgen metabolism. Biochimica et Biophysica Acta 1811 263-270. 
Majumdar SS, Bartke A \& Stumpf WE 1994 Vitamin D modulates the effects of follicle-stimulating hormone on Sertoli cell function and testicular growth in Siberian hamsters. Life Sciences 55 1479-1486. (doi:10.1016/ 0024-3205(94)00689-X)

Malloy PJ, Hochberg Z, Tiosano D, Pike JW, Hughes MR \& Feldman D 1990 The molecular basis of hereditary 1,25-dihydroxyvitamin $\mathrm{D}_{3}$ resistant rickets in seven related families. Journal of Clinical Investigation $\mathbf{8 6}$ 2071-2079. (doi:10.1172/JCl114944)

Masuda S, Byford V, Arabian A, Sakai Y, Demay MB, St-Arnaud R \& Jones G 2005 Altered pharmacokinetics of 1 1 ,25-dihydroxyvitamin $\mathrm{D}_{3}$ and 25-hydroxyvitamin $\mathrm{D}_{3}$ in the blood and tissues of the 25-hydroxyvitamin D-24-hydroxylase (Cyp24a1) null mouse. Endocrinology 146 825-834. (doi:10.1210/en.2004-1116)

Menegaz D, Barrientos-Duran A, Kline A, Silva FR, Norman AW, Mizwicki MT \& Zanello LP $20101 \alpha, 25(\mathrm{OH})_{2}$-Vitamin $\mathrm{D}_{3}$ stimulation of secretion via chloride channel activation in Sertoli cells. Journal of Steroid Biochemistry and Molecular Biology 119 127-134. (doi:10. 1016/j.jsbmb.2010.01.011)

Menegaz D, Mizwicki MT, Barrientos-Duran A, Chen N, Henry HL \& Norman AW 2011 Vitamin D receptor (VDR) regulation of voltage-gated chloride channels by ligands preferring a VDR-alternative pocket (VDR-AP). Molecular Endocrinology 25 1289-1300. (doi:10.1210/me. 2010-0442)

Meng J, Ohlsson C, Laughlin GA, Chonchol M, Wassel CL, Ljunggren $\mathrm{O}$, Karlsson MK, Mellstrom D, Orwoll ES, Barrett-Connor E et al. 2010 Associations of estradiol and testosterone with serum phosphorus in older men: the Osteoporotic Fractures in Men study. Kidney International 78 415-422. (doi:10.1038/ki.2010.161)

Merke J, Kreusser W, Bier B \& Ritz E 1983 Demonstration and characterisation of a testicular receptor for 1,25-dihydroxycholecalciferol in the rat. European Journal of Biochemistry 130 303-308. (doi:10.1111/j.1432-1033.1983.tb07152.x)

Merke J, Hugel U \& Ritz E 1985 Nuclear testicular 1,25-dihydroxyvitamin $\mathrm{D}_{3}$ receptors in Sertoli cells and seminiferous tubules of adult rodents. Biochemical and Biophysical Research Communications 127 303-309. (doi:10.1016/S0006-291X(85)80159-5)

Morley JE, Perry HM III, Kaiser FE, Kraenzle D, Jensen J, Houston K, Mattammal M \& Perry HM Jr 1993 Effects of testosterone replacement therapy in old hypogonadal males: a preliminary study. Journal of the American Geriatrics Society 41 149-152.

Mosekilde L, Nielsen LR, Larsen ER, Moosgaard B \& Heickendorff L 2005 Vitamin D deficiency. Definition and prevalence in Denmark. Ugeskrift for Laeger 167 29-33.

Nagakura K, Abe E, Suda T, Hayakawa M, Nakamura H \& Tazaki H 1986 Inhibitory effect of $1 \alpha, 25$-dihydroxyvitamin $\mathrm{D}_{3}$ on the growth of the renal carcinoma cell line. Kidney International 29 834-840. (doi:10.1038/ki.1986.74)

Nangia AK, Butcher JL, Konety BR, Vietmeier BN \& Getzenberg RH 1998 Association of vitamin $\mathrm{D}$ receptors with the nuclear matrix of human and rat genitourinary tissues. Journal of Steroid Biochemistry and Molecular Biology 66 241-246. (doi:10.1016/S0960-0760(98)00039-9)

Nangia AK, Hill O, Waterman MD, Schwender CE \& Memoli V 2007 Testicular maturation arrest to testis cancer: spectrum of expression of the vitamin D receptor and vitamin D treatment in vitro. Journal of Urology 178 1092-1096. (doi:10.1016/j.juro.2007.05.009)

Nimptsch K, Platz EA, Willett WC \& Giovannucci E 2012 Association between plasma $25-\mathrm{OH}$ vitamin $\mathrm{D}$ and testosterone levels in men. Clinical Endocrinology 77 106-112. (doi:10.1111/j.1365-2265.2012. 04332.x)

Ohyama Y \& Yamasaki T 2004 Eight cytochrome P450s catalyze vitamin D metabolism. Frontiers in Bioscience 9 3007-3018. (doi:10. 2741/1455)

Oliveira AG, Dornas RA, Kalapothakis E, Hess RA, Mahecha GA \& Oliveira CA 2008 Vitamin $D_{3}$ and androgen receptors in testis and epididymal region of roosters (Gallus domesticus) as affected by epididymal lithiasis. Animal Reproduction Science 109 343-355. (doi:10.1016/j.anireprosci.2007.11.009)

Osmundsen BC, Huang HF, Anderson MB, Christakos S \& Walters MR 1989 Multiple sites of action of the vitamin D endocrine system: FSH stimulation of testis 1,25-dihydroxyvitamin $\mathrm{D}_{3}$ receptors. Journal of Steroid Biochemistry 34 339-343. (doi:10.1016/0022-4731(89)90105-2)
Otremski I, Lev-Ran M, Salama R \& Edelstein S 1997 The metabolism of vitamin $\mathrm{D}_{3}$ in response to testosterone. Calcified Tissue International $\mathbf{6 0}$ 485-487. (doi:10.1007/s002239900267)

Oury F, Sumara G, Sumara O, Ferron M, Chang H, Smith CE, Hermo L, Suarez S, Roth BL, Ducy P et al. 2011 Endocrine regulation of male fertility by the skeleton. Cell 144 796-809. (doi:10.1016/j.cell. 2011.02.004)

Panda DK, Miao D, Tremblay ML, Sirois J, Farookhi R, Hendy GN \& Goltzman D 2001 Targeted ablation of the 25-hydroxyvitamin D $1 \alpha$-hydroxylase enzyme: evidence for skeletal, reproductive, and immune dysfunction. PNAS 98 7498-7503. (doi:10.1073/pnas.1310 29498)

Pi M, Wu Y \& Quarles LD 2011 GPRC6A mediates responses to osteocalcin in $\beta$-cells in vitro and pancreas in vivo. Journal of Bone and Mineral Research 26 1680-1683. (doi:10.1002/jbmr.390)

Pilz S, Frisch S, Koertke H, Kuhn J, Dreier J, Obermayer-Pietsch B, Wehr E \& Zittermann A 2011 Effect of vitamin D supplementation on testosterone levels in men. Hormone and Metabolic Research 43 223-225. (doi:10.1055/s-0030-1269854)

Pitteloud N, Dwyer AA, DeCruz S, Lee H, Boepple PA, Crowley WF Jr \& Hayes FJ 2008 Inhibition of luteinizing hormone secretion by testosterone in men requires aromatization for its pituitary but not its hypothalamic effects: evidence from the tandem study of normal and gonadotropin-releasing hormone-deficient men. Journal of Clinical Endocrinology and Metabolism 93 784-791. (doi:10.1210/jc. 2007-2156)

Ponchon G, Kennan AL \& DeLuca HF 1969 "Activation" of vitamin D by the liver. Journal of Clinical Investigation 48 2032-2037. (doi:10.1172/ JCl106168)

Prosser DE \& Jones G 2004 Enzymes involved in the activation and inactivation of vitamin D. Trends in Biochemical Sciences 29 664-673. (doi:10.1016/j.tibs.2004.10.005)

Publicover S, Harper CV \& Barratt C $2007\left[\mathrm{Ca}^{2+}\right]_{\mathrm{i}}$ signalling in spermmaking the most of what you've got. Nature Cell Biology 9 235-242. (doi:10.1038/ncb0307-235)

Ramlau-Hansen $\mathrm{CH}$, Hansen $\mathrm{M}$, Jensen CR, Olsen J, Bonde JP \& Thulstrup AM 2010 Semen quality and reproductive hormones according to birthweight and body mass index in childhood and adult life: two decades of follow-up. Fertility and Sterility 94 610-618. (doi:10.1016/j.fertnstert.2009.01.142)

Ramlau-Hansen CH, Moeller UK, Bonde JP, Olsen J \& Thulstrup AM 2011 Are serum levels of vitamin D associated with semen quality? Results from a cross-sectional study in young healthy men Fertility and Sterility 95 1000-1004. (doi:10.1016/j.fertnstert.2010.11.002)

Rapado A, Hawkins F, Sobrinho L, az-Curiel M, Galvao-Telles A, Arver S, Melo GJ, Mazer N, Garcia e Costa J, Horcajada C et al. 1999 Bone mineral density and androgen levels in elderly males. Calcified Tissue International 65 417-421. (doi:10.1007/s002239900726)

Ritz E, Kreusser W, Boland R \& Bommer J 1979 Vitamin D metabolism in kidney insufficiency: disorders of an endocrine regulatory zone. Klinische Wochenschrift 57 1053-1059. (doi:10.1007/BF01479991)

Robertson KM, O'Donnell L, Jones ME, Meachem SJ, Boon WC, Fisher CR, Graves KH, McLachlan RI \& Simpson ER 1999 Impairment of spermatogenesis in mice lacking a functional aromatase (cyp 19) gene. PNAS 96 7986-7991. (doi:10.1073/pnas.96.14.7986)

Rosen H, Reshef A, Maeda N, Lippoldt A, Shpizen S, Triger L, Eggertsen G, Bjorkhem I \& Leitersdorf E 1998 Markedly reduced bile acid synthesis but maintained levels of cholesterol and vitamin D metabolites in mice with disrupted sterol 27-hydroxylase gene. Journal of Biological Chemistry 273 14805-14812. (doi:10.1074/jbc.273.24.14805)

Ross AC 2011 The 2011 report on dietary reference intakes for calcium and vitamin D. Public Health Nutrition 14 938-939. (doi:10.1017/ S1368980011000565)

Rosso A, Pansera M, Zamoner A, Zanatta L, Bouraima-Lelong H, Carreau S \& Silva FR $20111 \alpha, 25(\mathrm{OH})(2)$-vitamin D(3) stimulates rapid plasma membrane calcium influx via MAPK activation in immature rat Sertoli cells. Biochimie 94 146-154. (doi:10.1016/j.biochi.2011.10.001)

Schleicher G, Privette TH \& Stumpf WE 1989 Distribution of soltriol $\left[1,25(\mathrm{OH})_{2}\right.$-vitamin $\left.\mathrm{D}_{3}\right]$ binding sites in male sex organs of the mouse: an autoradiographic study. Journal of Histochemistry and Cytochemistry 37 1083-1086. (doi:10.1177/37.7.2543697) 
van Schoor NM, Visser M, Pluijm SM, Kuchuk N, Smit JH \& Lips P 2008 Vitamin D deficiency as a risk factor for osteoporotic fractures. Bone 42 260-266. (doi:10.1016/j.bone.2007.11.002)

Sharpe RM, McKinnell C, Kivlin C \& Fisher JS 2003 Proliferation and functional maturation of Sertoli cells, and their relevance to disorders of testis function in adulthood. Reproduction 125 769-784. (doi:10.1530/ rep.0.1250769)

Skakkebaek NE, Giwercman A \& de Kretser D 1994 Pathogenesis and management of male infertility. Lancet 343 1473-1479. (doi:10.1016/ S0140-6736(94)92586-0)

Small M, Beastall GH, Semple CG, Cowan RA \& Forbes CD 1984 Alteration of hormone levels in normal males given the anabolic steroid stanozolol. Clinical Endocrinology 21 49-55. (doi:10.1111/j.1365-2265.1984. tb00135.x)

Sonnenberg J, Luine VN, Krey LC \& Christakos S 1986 1,25-Dihydroxyvitamin $D_{3}$ treatment results in increased choline acetyltransferase activity in specific brain nuclei. Endocrinology 118 1433-1439. (doi:10. 1210/endo-118-4-1433)

Sood S, Reghunandanan R, Reghunandanan V, Marya RK \& Singh PI 1995 Effect of vitamin D repletion on testicular function in vitamin D-deficient rats. Annals of Nutrition and Metabolism 39 95-98. (doi:10.1159/ 000177848)

St-Arnaud R 1999 Targeted inactivation of vitamin D hydroxylases in mice. Bone 25 127-129. (doi:10.1016/S8756-3282(99)00118-0)

St-Arnaud R, Arabian A, Travers R, Barletta F, Raval-Pandya M, Chapin K, Depovere J, Mathieu C, Christakos S, Demay MB et al. 2000 Deficient mineralization of intramembranous bone in vitamin D-24-hydroxylaseablated mice is due to elevated 1,25-dihydroxyvitamin D and not to the absence of 24,25-dihydroxyvitamin D. Endocrinology 141 2658-2666. (doi:10.1210/en.141.7.2658)

Strauss KI, Isaacs KR, Ha QN \& Jacobowitz DM 1994 Calretinin is expressed in the Leydig cells of rat testis. Biochimica et Biophysica Acta 1219 435-440.

Streeten EA, Zarbalian K \& Damcott CM 2011 CYP24A1 mutations in idiopathic infantile hypercalcemia. New England Journal of Medicine 365 1741-1742. (doi:10.1056/NEJMc1110226)

Stumpf WE, Sar M, Chen K, Morin J \& DeLuca HF 1987 Sertoli cells in the testis and epithelium of the ductuli efferentes are targets for $3 \mathrm{H} \mathrm{1,25}$ $(\mathrm{OH})_{2}$ vitamin $\mathrm{D}_{3}$. An autoradiographic study. Cell and Tissue Research 247 453-455. (doi:10.1007/BF00218327)

Tanaka Y, Castillo L \& DeLuca HF 1976 Control of renal vitamin D hydroxylases in birds by sex hormones. PNAS 73 2701-2705. (doi:10.1073/pnas.73.8.2701)

Thuesen B, Husemoen L, Fenger M, Jakobsen J, Schwarz P, Toft U, Ovesen L, Jorgensen T \& Linneberg A 2011 Determinants of vitamin D status in a general population of Danish adults. Bone 50 605-610. (doi:10.1016/j.bone.2011.12.016)

Uhland AM, Kwiecinski GG \& DeLuca HF 1992 Normalization of serum calcium restores fertility in vitamin D-deficient male rats. Journal of Nutrition 122 1338-1344.

Valimaki VV, Alfthan H, Ivaska KK, Loyttyniemi E, Pettersson K, Stenman UH \& Valimaki MJ 2004 Serum estradiol, testosterone, and sex hormone-binding globulin as regulators of peak bone mass and bone turnover rate in young Finnish men. Journal of Clinical Endocrinology and Metabolism 89 3785-3789. (doi:10.1210/jc.2003032187)
Van Cromphaut SJ, Rummens K, Stockmans I, Van HE, Dijcks FA, Ederveen AG, Carmeliet P, Verhaeghe J, Bouillon R \& Carmeliet G 2003 Intestinal calcium transporter genes are upregulated by estrogens and the reproductive cycle through vitamin $D$ receptor-independent mechanisms. Journal of Bone and Mineral Research 18 1725-1736. (doi:10.1359/jbmr.2003.18.10.1725)

Walters MR 1984 1,25-Dihydroxyvitamin $D_{3}$ receptors in the seminiferous tubules of the rat testis increase at puberty. Endocrinology 114 2167-2174. (doi:10.1210/endo-114-6-2167)

Walters MR, Cuneo DL \& Jamison AP 1983 Possible significance of new target tissues for 1,25-dihydroxyvitamin $\mathrm{D}_{3}$. Journal of Steroid Biochemistry 19 913-920. (doi:10.1016/0022-4731(83)90034-1)

Wang Y, Becklund BR \& DeLuca HF 2010 Identification of a highly specific and versatile vitamin D receptor antibody. Archives of Biochemistry and Biophysics 494 166-177. (doi:10.1016/j.abb.2009.11.029)

Wehr E, Pilz S, Boehm BO, Marz W \& Obermayer-Pietsch B 2010 Association of vitamin D status with serum androgen levels in men. Clinical Endocrinology 73 243-248. (doi:10.1111/j.1365-2265.2010.03852.x)

Weissgerber P, Kriebs U, Tsvilovskyy V, Olausson J, Kretz O, Stoerger C, Vennekens R, Wissenbach U, Middendorff R, Flockerzi V et al. 2011 Male fertility depends on $\mathrm{Ca}(2)+$ absorption by TRPV6 in epididymal epithelia. Science Signaling 4 ra27. (doi:10.1126/scisignal.2001791)

WHO 2010 WHO laboratory manual for the examination and processing of human semen. World Health Organization, Department of Reproductive Health and Research. 5th edn, pp 1-287.

Yoshizawa T, Handa Y, Uematsu Y, Takeda S, Sekine K, Yoshihara Y, Kawakami T, Arioka K, Sato H, Uchiyama Y et al. 1997 Mice lacking the vitamin D receptor exhibit impaired bone formation, uterine hypoplasia and growth retardation after weaning. Nature Genetics 16 391-396.

Yu HM, Li XJ, Kadam AL, Cheng CY \& Koide SS 1994 Human testis vitamin $\mathrm{D}$ binding protein involved in infertility. Archives of Andrology 33 119-128. (doi:10.3109/01485019408987813)

Zanatta L, Bouraima-Lelong H, Delalande C, Silva FR \& Carreau S 2011a Regulation of aromatase expression by $1 \alpha, 25(\mathrm{OH})_{2}$ vitamin $\mathrm{D}_{3}$ in rat testicular cells. Reproduction, Fertility, and Development 23 725-735. (doi:10.1071/RD10163)

Zanatta L, Zamoner A, Goncalves R, Zanatta AP, Bouraima-Lelong H, Carreau S \& Silva FR 2011b 1 $\alpha, 25$-Dihydroxyvitamin D(3) signaling pathways on calcium uptake in 30-day-old rat Sertoli cells. Biochemistry 50 10284-10292. (doi:10.1021/bi201113n)

Zanatta L, Zamoner A, Zanatta AP, Bouraima-Lelong H, Delalande C, Bois C, Carreau S \& Silva FR 2011c Nongenomic and genomic effects of $1 \alpha, 25(\mathrm{OH})_{2}$ vitamin $\mathrm{D}_{3}$ in rat testis. Life Sciences 89 515-523. (doi:10. 1016/j.Ifs.2011.04.008)

Zofkova I \& Kancheva RL 1996 Effect of estrogen status on bone regulating hormones. Bone 19 227-232. (doi:10.1016/8756-3282(96)00173-1)

Zofkova I, Sotornik I \& Kancheva RL 1996 Adenohypophyseal-gonadal dysfunction in male haemodialyzed patients before and after subtotal parathyroidectomy. Nephron 74 536-540. (doi:10.1159/000189448)

Received 27 February 2012

First decision 19 March 2012

Revised manuscript received 17 May 2012

Accepted 25 May 2012 